\title{
Corporate Governance in China: Then and Now
}

\author{
By: Cindy A. Schipani and Liu Junhai
}

William Davidson Working Paper Number 407

November 2001 


\title{
CORPORATE GOVERNANCE IN CHINA: THEN AND NOW
}

\author{
by
}

\author{
Cindy A. Schipani* and Liu Junhai**
}

\begin{abstract}
Corporate governance has become a globally debated topic. ${ }^{1}$ As multinational corporations enter new global markets, complications abound dye to the myriad of corporate governance rules existing among the various legal systems. One example of the new markets becoming more available to American investment is the Chinese market. In light of both the grant of permanent normal trade relations (PNRR) to China 3 and China's anticipated membership in the World Trade Organization (WTO) the American business community is apt to find more opportunity for investment in China.

American investors are likely to be increasingly interested in understanding the current Chinese corporate governance regime as they consider the Chinese market for investment of their assets. The goal of this paper is to provide an analysis of the corporate governance system in China and offer some suggestions for improvement to make the Chinese market more attractive to foreign investors.

This paper is organized as follows. Part I provides general background information on the historical corporate governance structures prevalent in China. Part II then analyzes current governance issues, in particular those occurring in the context of corporatization of China's State-owned enterprises. Part III offers proposals for reform and is followed in Part IV by our concluding remarks.
\end{abstract}

Keywords: corporate governance; law reform; China; corporate law

*Professor of Business Law, University of Michigan; Area Director for Corporate Governance and Social Responsibility, William Davidson Institute at the University of Michigan Business School. J.D. 1982, University of Chicago; B.A. 1979, Michigan State University.

Contact address: University of Michigan Business School, Ann Arbor, MI 48109

e-mail: schipani@umich.edu

**Associate Professor of Business Law, Institute of Law, Chinese Academy of Social Sciences. J.S.D, Chinese Academy of Social Sciences, 1995. LLM, China University of Political Sciences and Law, 1992; LLB, Hebei University, 1989. The authors wish to gratefully acknowledge Dr. Erika O. Parker, the University of Michigan Business School and the William Davidson Institute for support of this project.

e-mail: junhai@public.east.net.cn 


\section{A Historical Perspective - The State-Owned Enterprise (SOE)}

Traditionally, the production of goods and services in China has been conducted by state owned enterprises (SOEs). The SOE has evolved in China from a model where the State held all property ownership and managerial rights, to a contracting model where the enterprise became responsible for its own profits and losses, to a model that resembles a corporation in the United States. These SOE governance models can be classified as follows: (1) the traditional model (1950s to 1984); (2) the transitional model (1984 to 1993); and (3) the modern corporate model (1993 to present). An understanding of the history of the SOE governance model is essential to identifying proposals for modern corporate governance requirements for corporatization of SOEs. Salient features of the traditional and transitional models are described below. The modern corporate model is the topic of Part II.

\section{A. Traditional model (1950s to 1984)}

The traditional model of SOE governance could also be referred to as the State-ownership model, or the State-owned and managed model. This model was dominant from the 1950s through 1984. Under this model, State ownership was generally assumed to be the only legal form available to provide safeguard for State property. Not only did the State have ownership of all the property of the SOEs, but it also enjoyed managerial powers. The backbone rationale behind this model was paramount State property ownership.

Unfortunately, the concept of State ownership not only depressed the growth of private

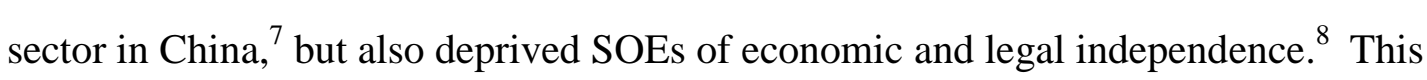
concept, developed in a planned economy, ${ }^{9}$ provided justification for State planners to mobilize human and financial resources and to decide production and distribution demands. The duties of SOE executives were to fulfill the production plans of the government, rather than enhance profits for the State investor. In other words, SOEs were not real business enterprises. The terms "corporation" or "legal person" did not exist in China during the 
central-planning period. Most SOEs were simply referred to as "factories"(Gongchang), and merely functioned as government affiliates responsible for producing goods or rendering services. 10

Accordingly, the governance structure in SOEs was an integral part of the general governmental framework. The executives of SOEs were appointed and dismissed by government agencies, and enjoyed the same political and economic treatment of government

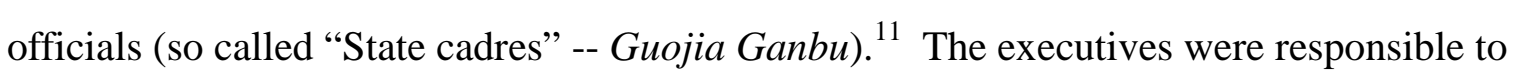
government agencies. Their achievements were not evaluated by the enterprises' financial performance, but by the enterprises' performance in satisfying the plans made by government agencies.

The traditional model not only served as an organizer of economic resources and activities, but also as a tool to firmly bind the State, SOEs and employees. State coffers were the sole source of SOEs input; SOEs and their employees effectively lived off of the SOE coffers. SOEs were thus both production units and social security units. Once a person entered an SOE, he or she gained a "iron rice bowl" which could be kept for life in terms of salary, housing, medical treatment, and pension. SOE as a State-owned Working Unit (gongzuo danwei) had a rich and unusual meaning for Chinese employees, and could not be easily understood by their counterparts in the U.S. $\stackrel{12}{ }$ Unfortunately, most SOEs were static and uncompetitive.

\section{B. Transitional model (1984 to 1993)}

The transitional model of SOE governance is also referred to as the State-creditor's rights model, or the contracting model. This model was dominant from approximately 1984 through 1993, until the Corporate Law was enacted. As a strategy to encourage SOEs to expand production and to earn profits, SOE reform had been the main part of Chinese economic reforms since late $1970 \mathrm{~s} .{ }^{1.3}$ The goal of the reform initiatives was to make SOEs 
responsible for their own gains and losses in the market. In the official language, "SOEs should become legal persons that enjoy full management authority and full responsibility for their own profits and losses. ${ }^{, 14}$ One of the leading theories advocated by this reform initiative was "separation between the State ownership and the SOE management rights." 15 Policy-makers at the time believed that this was the best way to transform SOEs into legal entities, while simultaneously retaining State property ownership. To accomplish the reform objectives, the SOEs Law was adopted in 1988 (SOEs Law).

The SOEs Law of 1988 recognized that:

The property of the enterprise shall be owned by the whole people (equivalent to the notation of "State"), and shall be operated and managed by the enterprise with the authorization of the State based on the principle of the separation of ownership and right of management. The enterprise shall enjoy the rights to possess, use, and dispose of, according to law, $\frac{16}{6}$ the property, which the state has authorized it to operate and manage. The enterprise shall obtain the status of legal person in accordance with law and bear civil liability with the property, which the State has authorized it to operate and manage. The enterprise may, in accordance with the decision of competent government agencies, adopt contracting, leasing or other forms of [a] managerial responsibility system. 17

The corporate governance structure introduced by the SOEs Law of 1988 has three salient features. First, the factory director (manager) assumes overall responsibility for the enterprise management. 18 This means that the factory director acts as the legal representative of the enterprise, and exercises leadership in the production, operation and management of the enterprise. In other words "the factory director occupies the central position in the enterprise." 19 The law also imposed a requirement of establishing a management committee or another consulting body to be chaired by the factory director, to assist the factory director in making decisions on important issues. 20

Second, the SOEs Law provides that the local organization of the Chinese Communist Party in the enterprise guarantees and supervises the implementation of the guiding principles and policies of the Party and the State in the enterprise. ${ }^{21}$ Third, the enterprise is allowed, through the employees' congress and other forms, to practice democratic management, ${ }_{22}$ trade 
unions are permitted to represent and safeguard the employees' interests and employees may organize and participate in democratic management and supervision. 23

Between 1987 and 1993, the contracting system (Cheng Bao Zhi), was adopted in many SOEs to govern their relationship with the State and factory director. In April, 1987, the Central Committee of the Chinese Communist Party and the State Council adopted a contracting system in SOEs nationwide. ${ }^{44}$ According to contracting system, the two parties to the contract are the government agency and the SOE as represented by its chief executive officer (CEO). ${ }^{25}$ The CEOs of SOEs are selected through a competitive process. ${ }^{6}$ The CEOs act as the legal representatives of SOEs, and take full responsibility for managing their SOEs. 27 The basic principle of contracting system was to "lock the minimum amount of profit for the SOEs to pay to the State," and entitle SOEs "to keep the remaining profit, but [remain] liable for paying the fixed amount to the State even if [the] SOEs have not made satisfactory profit."

As a result of the contracting process, governmental intervention in the operation of SOEs was significantly diminished, and SOEs gained more freedom to make their own business decisions. The SOEs were allowed to retain part of their profits after completing the government's assignments. As an economist commented, with the help of the contracting system, "the State fiscal revenue was reasonably increased. The loss-making SOEs only accounted for $10 \%$ among all the SOEs. There was no enterprise having difficulties in paying their employees, and there was no enterprise going bankrupt or laying off their employees." 29

But the contracting system and the transitional model it represented failed to provide much in the way of SOE reform for a number of reasons. First, it was very difficult to identify a reasonable minimum amount of profit for the SOEs to pay to the State. ${ }^{0}$ Second, although most SOEs enjoyed benefits when they were profitable, they were unable to pay the fixed 
amounts required to the State when they sustained losses. 13 Third, there was a fair amount of exploitation of the assets of SOEs for personal use. ${ }^{32}$ Finally, too little SOE profit was retained for development purposes, leaving insufficient resources for future expansion. 3 With these problems in mind, SOE reform in 1993 reflected a desire to building a modern enterprise system compatible with market economy. ${ }^{34}$ To achieve this goal, Chinese policy makers began to look to the modern corporation model in the Western world for possible solutions.

\section{Modern Corporate Model (1993 - Present)}

After the late paramount leader, Mr. Deng Xiaoping called for an introduction of the market economy in China in 1992, one of the goals of SOE reform was officially identified as to "set up [a] modern enterprise system (modern corporation system) ${ }^{3.5}$ in the majority of backbone large and medium-sized SOEs." ${ }^{6}$ SOE reform policy also accelerated the process of corporate legislation, which was perceived as an essential legal instrument for corporatizing SOEs. 7

China is in the process of restructuring many traditional SOEs. The corporations restructured from traditional SOEs in China are referred to as SOE-corporatized corporations. Compared with traditional SOEs, the ownership structure of SOE-corporatized corporations include more well-defined shareholder rights than its traditional counterpart, and promotes more efficiency and accountability. In comparison with corporations held by individuals or private institutions, SOE-corporatized corporations are expected to present more sophisticated and difficult governance issues during the current transition period from the planned economy to the market economy in China.

The Corporate Law of 1993 provides solid legal foundations for transformation of SOEs into different business corporations, including wholly State-owned corporations, closely held corporations and publicly held corporations. 


\section{A. The Corporate Law}

In China today, the most important legal sources of corporate governance rules are the laws passed by the National Peoples' Congress (NPC) ${ }^{88}$ and its Standing Committee. ${ }^{99}$ These laws include the Corporate Law of 1993 (Corporate Law), ${ }_{0.0}$ and the Securities Law of 1998 (Securities Law). 1 In addition to legal sources, the memorandum of associations (Gongsi Zhangcheng $)^{42}$ of each corporation plays an active role in designing each corporation's corporate governance structure. The Chinese memorandum of associations is comparable to a document that would combine both the articles of incorporation and bylaws of American corporations.

The Corporate Law (Law) requires corporations to form three statutory and indispensable corporate governing bodies: (1) the shareholders, acting as a body at the general meeting; (2) the board of directors; and (3) the board of supervisors. ${ }^{4}$ In addition, the Law introduced two statutory corporate positions - the chair of board of directors (chair) and the chief executive officer.

At first glance, the Chinese corporate governance structure may appear similar to the two-tier system of corporate governance in Germany. The German corporation is also governed by a board of directors and a supervisory board. ${ }^{46}$ However, there are substantial differences between the German and Chinese systems. For instance, there is no hierarchical relation between the board of directors and the board of supervisors in China, and both directors and supervisors are appointed by, and may be dismissed by, action of the shareholders. ${ }^{47}$ In contrast, the German supervisory board oversees the board of directors, and the members of the board of directors are appointed by, and may be dismissed by, the board of supervisors.

Chinese corporate law recognizes only two types of corporations: closely held corporations (Youxian Zeren Gongsi) and publicly held corporations (Gufen Youxian 
Gongsi). ${ }^{9}$ Within each category of corporation, there are special provisions applicable to subcategories, organized according to the corporation's ownership structure. The governing bodies in closely and publicly held corporations are substantially the same.

\section{Closely Held Corporations}

Although governance rules for closely held corporations are similar to those of publicly held corporations, Chapter 2 of the Corporate Law contains a number of special provisions applicable only to closely held corporations. For example, a corporation with "few shareholders" and "small capital size" is not required to set up a board of directors, instead it is required only to have a single executive director and the executive director may serve concurrently as the manager. In addition, this type of corporation does not need an entire board of supervisors, one or two supervisors will suffice. 1 Although in general the voting rights of shareholders in closely held corporations are exercised in proportion to their capital contributions, ${ }_{52}$ in the situation where a shareholder wishes to assign its capital contribution to non-shareholders, the consent of greater than $50 \%$ of the total number of shareholders is required.

The Corporate Law has different rules for closely held corporations wholly-owned by the State as opposed to those that include a foreign investor. These rules are discussed below.

\section{a. Wholly State-owned corporations}

A wholly State-owned corporation is defined as "a limited liability corporation invested and established solely by the State-authorized investment institutions or government agencies." 44 Under the Corporate Law as originally enacted, there were only two corporate bodies statutorily required in wholly State-owned corporations: the board of directors and the CEO. Because there are no general meetings of shareholders and no board of supervisors in state-owned corporations, the board of directors and the CEO have more governing powers than their counterparts in other types of corporations. State-authorized investment 
institutions or government agencies have the power to make decisions on important corporate issues. 55 Certain types of transactions, such as corporate mergers, divisions, dissolutions, increases and reductions of capital, and issuance of corporate bonds, may only be decided by the State-authorized investment institutions or government agencies. 66

With generous powers in the hands of insiders of wholly State-owned corporations, many senior executives in SOEs prefer to transform their SOEs into wholly State-owned corporations. ${ }^{57}$ Unfortunately, though, the generous powers provided to the management of wholly State-owned corporations have led to management irresponsibility in recent years. In order to strengthen the supervisory mechanism in wholly State-owned corporations (and therefore, to address the problem of corruption), the Standing Committee of the NPC amended the Corporate Law on December 25 of 1999 to require wholly State-owned corporations to establish boards of supervisors, whose members shall be chosen by the State Council, or by the State-authorized investment institutions, or by government agencies. 99 Under this amendment, the number of supervisors shall be no fewer than three, and the board of supervisors should include at least one employee representative. ${ }^{6}$ In addition to the power to examine corporate financial affairs and to supervise directors and executives, the board of supervisors also enjoys other powers delegated by the State Council. 61

\section{b. Foreign invested corporations}

Another special provision applicable to closely held corporations concerns those that are foreign invested. In China, there are three types of foreign invested corporations: (1) wholly foreign-invested enterprises; (2) Chinese-foreign equity joint ventures; and (3) Chineseforeign contractual joint ventures. These types of foreign invested corporations are governed by three separate laws: the Wholly Foreign-Invested Enterprises Law of 1986, 22 the ChineseForeign Equity Joint Ventures Law of $1979, \frac{63}{2}$ and the Chinese-Foreign Contractual Joint Ventures Law of 1988, 4 respectfully. These three statutes were enacted before the enactment 
of the Corporate Law, thus the relationship between the foreign investment legislation and the Corporate Law is left unclear. The Corporate Law attempts to address this issue by providing that the Corporate Law "shall apply to limited liability corporations with foreign investment; where legislation on Chinese-foreign equity joint ventures, Chinese-foreign contractual joint ventures and wholly foreign-invested enterprises provide otherwise, such provisions shall prevail."

It is expected that China will join the WTO in the near future, and thus will become obligated to provide national treatment to foreign investors coming from other WTO members. Once this occurs, it is also expected that the statutes regulating foreign investments will be repealed, and Chinese-invested corporations and foreign-invested corporations will be governed by the same corporate governance norms.

\section{Wholly foreign-invested enterprises}

Wholly foreign-invested enterprises may take different legal forms, such as a corporation, partnership or sole proprietorship. The Wholly Foreign-Invested Enterprises Law 66 is generally silent on corporate governance structure. The corporate governance structure of these entities is therefore governed by the law applicable to their specific form of entity.

\section{Chinese-foreign equity joint ventures}

Chinese-foreign equity joint ventures must be organized as closely held corporations, 67 but neither a general meeting of shareholders nor a board of supervisors is required. The composition of the board of directors is to be stipulated in the contract and the memorandum of associations after negotiation among the shareholders. The Chair and the Vice-Chair shall be chosen through consultation by the parties to the venture, or elected by the board of directors. If the Chinese party or the foreign party takes the office of the Chair, the other party shall assume the office of the vice-Chair. The CEO and associate CEO shall be chosen 
from the various shareholders. 68

\section{Chinese-foreign contractual joint ventures}

Both equity joint ventures and contractual joint ventures are invested by foreign corporations, enterprises, economic entities and individuals in collaboration with Chinese corporations, enterprises and economic entities. There are, however, a number of differences between equity joint ventures and contractual joint ventures. First, equity joint ventures must take the form of closely held corporations. ${ }^{69}$ This organizational form is not required for contractual joint ventures. Only contractual joint ventures may acquire the status of a Chinese legal person in accordance with law. ${ }^{0}$ Second, the investors of equity joint ventures share dividends and undertake risks and losses in accordance with the percentage of shareholding in the registered capital, 1, whereas the investors of contractual joint ventures share dividends or products and undertake risks and losses in accordance with the agreements prescribed in the contractual joint venture contract. ${ }^{22}$ Third, the investors of equity joint ventures usually receive monetary dividends,,${ }^{63}$ while the investors of contractual joint ventures could receive either monetary dividends or products as the form of investment return. Fourth, foreign investors of contractual joint ventures may seek return of their capital contribution before the company is wound up, if all of the fixed assets of the contractual joint venture belong to the Chinese party, and if agreed to by both the Chinese and the foreign parties. ${ }^{64}$ In most other respects, contractual joint ventures organized as closely held corporations are governed in a similar manner as equity joint ventures.

\section{Publicly Held Corporations}

A publicly held corporation is also called a joint stock limited company (Gufen Youxian Gongsi). The Corporate Law defines a publicly held corporation as a corporation in which the "total capital shall be divided into equal shares, shareholders shall assume liability towards the company to the extent of their respective shareholdings, and the corporation shall 


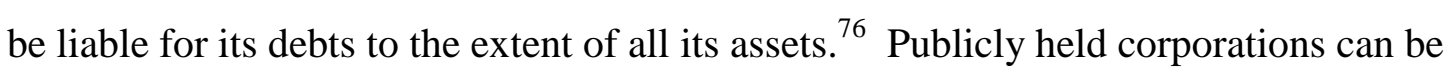
categorized into listed corporations, and non-listed corporations. A listed corporation refers to "a joint stock limited corporation which has its issued shares listed and traded at stock exchanges with the approval of the State Council or the department of securities administration authorized by the State Council." ${ }^{17}$ The shares of a non-listed corporation are not listed on a stock exchange. Publicly held corporations are governed by both the Corporate Law ${ }^{18}$ and the Securities Law.

\section{B. Modern SOEs}

The modern SOE is governed today both by the SOEs Law of 1988 and the Corporate Law of 1993. The SOEs Law requires modern SOEs to: (1) clearly establish ownership; (2) provide well-defined rights and responsibilities; (3) separate the enterprise from government; and (4) employ principles of scientific management. 80

Pursuant to the requirement of clearly established ownership, shareholders of modern SOEs are entitled to enjoy their shareholders' rights in proportion to their shares, and are obligated to transfer the ownership of their investment to the corporation. ${ }^{\text {Further, }}$ corporations enjoy full ownership over the capital contributed by shareholders, as well as ownership of the profits and properties subsequently acquired by the corporation. Shareholders are also entitled to dividends after the dividends are declared, and to net assets when the corporation is liquidated. Finally, the shareholder's personal property, including their capital investment, is separate and independent from the corporation's property.

The phrase "well-defined rights and responsibilities" refers to a clear and certain delineation of rights, obligations and liabilities between and among the corporation, shareholders, employees, creditors, consumers and other stakeholders. Eight legal relationships are specifically enumerated. These are: (1) the relationship between the corporation and its shareholders including a corporate parent; (2) shareholder relationships 
among themselves: (3) the fiduciary relationship between a corporation and its directors, supervisors and top management; (4) the relationship between a corporation and its creditors; (5) the relationship between shareholders and creditors; (6) the legal relationship between a corporation and its employees; (7) the relationship between a corporation and its competitors; and (8) the relationship the corporation has with its consumers.

The SOEs Law also promotes a policy of separation of government from the enterprise. However, as will be discussed below, this goal has been somewhat difficult to achieve.

The term "scientific management" was coined to tackle the problems of "random decision-making, relaxed management, undisciplined job performances, and low-level managerial abilities" ${ }^{\prime \prime 2}$ inherent in SOEs. Scientific management describes the goals of achieving democratic decision-making processes, efficient execution, and strong supervision over decision-making. Reaching these goals requires establishment of effective mechanisms of incentive and restraint, and checks and balances inside the corporate governance structure.

The Corporate Law of 1993 also provides generous privileges for SOE-corporatized corporations, which are unavailable to other corporations. For instance, "there must be five or more sponsors for incorporating a publicly held corporation, while a waiver is granted where a SOE is restructured into publicly held corporation." 33 Another example of a privilege is that "publicly held corporation, a wholly State-owned corporation, and a closely held corporation incorporated by two or more SOEs or State-owned investment entities may, for the purpose of raising funds for its production and operation, issue corporate bonds." Other closely held corporations are not qualified to issue corporate bonds.

Beginning in early 1992, some SOEs began to be corporatized on pilot basis. Since 1994, after implementation of the Corporate Law, government agencies have been making further efforts to push forward SOE corporatization. The Central government selected 100 SOEs for corporatization. ${ }^{8.5}$ Based on a survey conducted by the Department of Enterprise 
Reforms,,$\frac{86}{\text { ninety-eight SOEs had been corporatized by the end of } 1998 .}$ One SOE became bankrupt and the other failed to provide information for the survey. Among the other SOEs, sixteen were transformed into publicly held corporations, sixteen were transformed into closely held corporations, and sixty-two were transformed into wholly State-owned corporations with various subsidiaries. 88 Four SOEs still operate under the traditional enterprise regime. ${ }^{69}$ During the period between 1995 and 1998, forty-eight pilot SOEs were transformed into listed corporations, or parent corporations of listed subsidiaries, and raised funds of RMB 3.9 billion Yuan from overseas securities markets. 00

Corporate governance changes do not necessarily produce immediate profits, however. In a survey conducted by the China Confederation of Enterprises in 1999 of over 1,235 SOE managers (Confederation of Enterprises Survey), 1 only $14 \%$ of the managers reported better

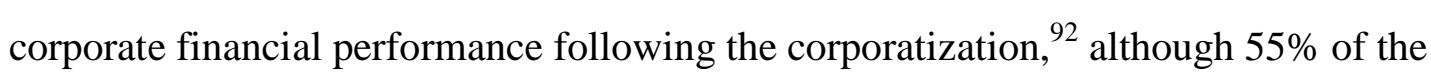
respondents reported better corporate governance. 93

As a pillar of China's national economy, SOEs have significant social and political implications for contemporary China. However, due in large part to the side effects of several decades of a highly centralized economy and radical changes in market conditions, many SOEs have run into serious financial difficulties. According to the Ministry of Finance, "there are 238,000 non-commercial SOEs with RMB 13,500 billion Yuan (US\$1,626.5 billion) of State assets in 1998. The number of large SOEs is only 9,357, and medium-sized and small SOEs account for $96 \%$ of total SOEs. However, more than $45 \%$ of the assets are owned by the smaller firms, which in many cases engage in low-level repetitive production and are not competitive." ${ }^{14}$ In early 1999, "about $49 \%$ of Chinese large and medium-sized SOEs are suffering the loss." 5

Moreover, it appears that internal corporate governance itself is in need of improvement in most SOEs. For instance, although the governing corporate bodies in many SOE- 
corporatized corporations have been established, they do not function very well. According to a survey conducted by State Committee of Economy and Trade, only twenty-two of ninetyeight corporations have been conducting meetings of shareholders. 6 Among the twenty-two corporations which have been holding meetings of shareholders, the meetings have been properly conducted in only eleven of these corporations. ${ }^{-7}$ The meetings of shareholders in seven corporations have been relatively effective, and the meetings of shareholders in four corporations have been moderately effective.

On the other hand, ninety of ninety-eight corporations have set up boards of directors. Most boards of directors (seventy-five) have been functioning very well, while in the other fifteen corporations, boards play a limited role. Seventy-eight of the ninety-eight corporations have set up boards of supervisors. Two-thirds of the boards of supervisors have been functioning well.

As far as the appointment of executives is concerned, government agencies have been playing decisive roles in fifty-two corporations, and boards of directors have been playing decisive roles in thirty-five corporations. Other approaches have been adopted in ten corporations. In short, twenty-nine pilot corporations admit that their corporate bodies have been functioning irregularly.

In addition to the 100 pilot samples mentioned above, other SOE-corporatized corporations as well as listed corporations have been facing similar governance problems. Although many SOEs have been transformed into business corporations, their managements still tend to avoid the corporate governance requirements imposed by the Corporate Law and retain the traditional SOE governance model. ${ }^{100}$ Some listed corporations do not convene regular meetings of board of directors, thus there is little check on managerial power. 01 There are also some directors who do not take the board meeting rules seriously. ${ }^{102}$ In some corporations, all directors act as managers and executives. ${ }^{103}$ The excessive overlaps between 
directors and executives frequently cause problems of insider control and managerial

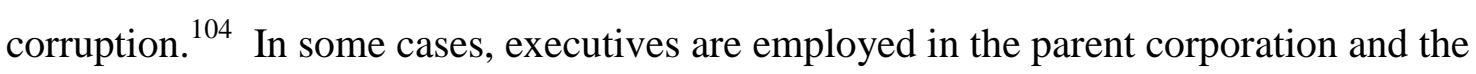
subsidiary at the same time, and these dual positions greatly threaten and weaken the shareholders' powers. In corporations with highly centralized shareholding structures, the controlling shareholders are extremely dominant and, therefore, minority shareholders are unable to enjoy proper protection. $\frac{105}{}$ Although several listed corporations, including Zhongxing Communication Co., Jiangnan Heavy Industry Co., and Xiaoya Electricity Co. have attempted to introduce independent directors and supervisors, the reality is that serious governance problems still exist. 106

\section{Proposals for Governance Reform}

As noted above, in spite of current efforts at reform, improvements are needed in Chinese corporate governance. This Part identifies some of the issues that need to be addressed in order to achieve further governance reform in SOE-corporatized corporations and offers some modest suggestions.

\section{A. Repeal SOEs Law}

The SOEs Law of 1988 was enacted in connection with the transitional model of corporate governance whereas the Corporate Law of 1993 is aimed at governing modern corporations. Today, many SOEs are still governed by the SOEs Law and its regulations. In

many cases, provisions of the Corporate Law and the SOEs Law and regulations conflict. 107 As a first step in reform, we propose that as China corporatizes its SOEs, the SOEs Law and its subordinate regulations should be repealed. Instead, all SOEs, should be governed by the Corporate Law. This not only simplifies corporate governance, it applies the most current Chinese thinking to all of its corporate enterprises.

\section{B. Build Autonomy}

Historically, the government has played a key role in corporate governance. In the 
period of the planned economy, the civil society was almost replaced by the political state, and SOEs and government agencies were to a great extent commingled. Moreover, SOEs were generally regarded as government branches. Although some people described the relationship between the government and SOE as "the relationship between a father and his son," it is more accurate to describe it as the relationship between "a father and his hand," because an SOE, like a hand, did not have its own legal independence.

China is in a transition period from a planned economy to a market economy. Some government agencies still treat SOE-corporatized corporations like traditional SOEs, and control them in the traditional ways with excessive administrative power. This control includes requiring approval of decisions already made by the board of directors, bypassing the general meeting of shareholders and directly appointing directors and executives, and interfering with daily operations. For example, a survey in early 1999 reveals that "of the enterprises which are undergoing the reform of establishing a modern enterprise system, officials are still nominated by government departments instead of the board of directors." 109 In the survey conducted by China Confederation of Enterprises, $46 \%$ of the respondent managers replied that they preferred to be selected by the board of directors, and only $7 \%$ said that they prefer to be selected by government agencies. $\frac{110}{1}$ Approximately $51 \%$ of the respondents believe that their most difficult job was to maintain a good relationship with government agencies. ${ }^{111}$ Although $56 \%$ of the managers said that excessive fee collection as well as excessive fine and donation solicitation from the government agencies has been mitigated, $11 \%$ of them believe that the problem is still very serious, and $33 \%$ believe that this problem is still serious. ${ }^{112}$ The survey also revealed that most managers are so busy dealing with unlimited and repeated inspections and examinations organized by government agencies that their business management is compromised.

The survey conducted by the Confederation of Enterprises also revealed that only $8 \%$ of 
the managers are fully satisfied with the government restructuring progress which began in $1998,66 \%$ of the managers are basically satisfied with the process, and $25 \%$ are not satisfied. 114 Approximately $13 \%$ of the respondents said that corporations are unable to be independent from the government after government restructuring and SOE corporatization, $59 \%$ of the respondents are not sure about this question, and only $28 \%$ said that the corporations will become independent from the government.

With respect to management activities, over $50 \%$ of respondent managers reported that their SOEs have the right to buy materials, to sell products or services, to set up internal bodies, to decide the employees' salary and bonus, and to dispose of the SOE-owned funds. Around $25 \%$ of the respondent managers reported that their SOEs were unable to resist the improper donation requests from the government or other organizations, or resist governmental decisions with respect to joint ventures, mergers or disposition of enterprise assets. Approximately $81 \%$ of the respondent managers said that they are appointed by government agencies. The main reason for the absence of comprehensive business autonomy in many SOEs is the old system of inseparability or commingling between government and enterprises. ${ }^{117}$ As these surveys demonstrate, there is still a long way to go before SOEs and SOE-corporatized corporations become truly independent from the government agencies.

In order to build sound corporate governance and corporate autonomy, it is imperative to disassociate business corporations from government agencies, to reduce government intervention in business affairs, and substantially liberalize corporate business activities from government control. In fact, the Chinese government has recently recognized this principle, and promised to separate the government from corporate functions. 118

Yet, as agents of the State shareholder, government agencies should be permitted to exercise shareholders' rights on behalf the State shareholder, but not interfere in the daily corporate management and operations, or intervene in lawful corporate decision-making 
processes. The State shareholder should enjoy the same shareholder rights as the private investors. In terms of personnel and financial controls, however, government agencies should fully disassociate with the SOE-corporatized corporations under their control. 119

In light of their public role, it is appropriate for government agencies to intervene in the market in some ways, however. Governmental intervention can be useful for providing: respect for corporate autonomy; (2) protection of fair competition; (3) guidance of the microeconomy; (4) facilitation of achievement of corporate goals; and (5) fulfillment of business opportunities and other legitimate interests, including government procurement. $\frac{120}{\text { Micro- }}$ control legislation should give equal attention to the controller and the controlled and principles of legitimacy, efficiency, and fairness should be respected when government intervention is introduced.

Given the difference in the legal nature between private right and public power, the shareholder's rights enjoyed by the State and the administrative powers possessed by government agencies, should be separated, and should be exercised by different entities. In this regard, it is extremely important to identify the proper institutions or organizations acting as the agents of State shareholder.

\section{Redefine the Relationship Between Old and New Corporate Bodies}

Prior to adoption of the Corporate Law, the main governance bodies in the traditional SOEs were the committee of Communist Party, the trade union, and the meeting of employees' representatives in the traditional SOEs. As noted above, modern Chinese corporations are now governed by the general meeting of shareholders, the board of directors, and the board of supervisors. However, the old corporate bodies continue to play a role. It has been held that "[p]arty organizations should perform duties according to the Party Constitution, and trade unions and employees' congresses should carry out their respective

duties in accordance with relevant laws and regulations." ${ }^{12}$ Yet overlap between the new and 
the old corporate bodies is still possible. "Party committee leaders of wholly State-owned corporations and State share-holding corporations can be included in [the] board of directors and [the] board of supervisors in accordance with legal procedures, and employees' representatives should be included in the boards of directors and supervisors." ${ }^{122}$ Moreover, "[t]he Party secretary and the Chair of board of directors can be the same person, but in principle, the Chair of board of directors and chief executive officer should be two separate people." 123 Despite the roles of the old governing bodies, "it is necessary to give full play to the role of board of directors in making unified decisions on major issues and the effective supervisory role of board of supervisors. ${ }^{124}$ To achieve the objectives of the Corporate Law reforms, the three new corporate bodies created by the Corporate Law should be permitted to function independently.

\section{Improve the Function of the General Meeting of Shareholders}

The general meeting of shareholders in China is considered the supreme sovereignty

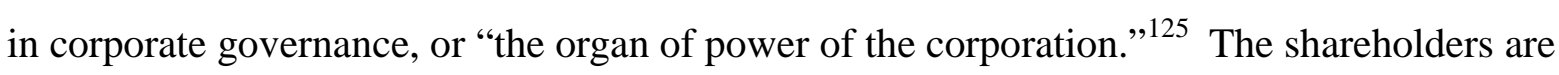
provided the following comprehensive decision-making powers at the general meeting by statute: (1) to make decisions regarding corporate policies on business operation and investment plans; (2) to elect and replace directors and to determine their remuneration; (3) to elect and replace shareholder supervisors and to determine their remuneration; (4) to examine and approve the reports of board of directors and of the board of supervisors; (5) to examine and approve plans of corporate fiscal financial budget and final accounts; (6) to examine and approve plans of corporate profit distribution and of making up of losses; (7) to make resolutions on the increase or the reduction of the corporation's registered capital; (8) to decide whether to issue corporate bonds; (9) to make decisions regarding corporate mergers, divisions, dissolution and liquidation; and (10) to amend corporate memorandum of associations. ${ }^{126}$ 
In the United States, some of these powers, such as the power to approve plans of corporate profit distribution and the power to determine the directors' remuneration, are reserved to the board of directors, rather than the shareholders. The rationale behind this institutional arrangement in China is that the shareholders are considered the ultimate source of authority. In other words, the powers enjoyed by the board of directors and the board of supervisors are derived from the shareholders, and not from the legislature. This corporate governance philosophy resembles the political governance philosophy expressed by the Chinese Constitution. Pursuant to the Constitution, the "NPC is the supreme State power organ." "127 "All the executive branches, judiciary branches and procurator branches shall be elected by people's congress, responsible to people's congress, and are subject to the supervision by people's congress." 128 In other words, the NPC is the supreme power center in the Chinese political life. All other state bodies derive their powers from the NPC. Given the similarities between the governance structure in the political states and that in business corporations, it was natural for the Chinese legislature to translate the rationale of the political governance regime into the corporate life, and to compare the meeting of shareholders to the NPC.

As Chinese Corporate Law undergoes further revision, the question is whether the general meeting of shareholders should keep its current powers, or whether some powers, especially substantial managerial powers, should be transferred to the board of directors. It is reasonable to maintain the status quo in order to deal with excessive managerial power, particularly during a transitional period. However, it may be wise to consider the corporate governance arrangements in other legal systems, and perhaps reduce some powers currently possessed by the shareholders, in order to harmonize the Chinese system of corporate governance with global investment requirements.

We propose some refinement in the Corporate Law. The current Corporate Law lists 
statutory powers enjoyed by the shareholders and the board of directors. By granting various powers to both bodies, it is unclear which body prevails in the case of conflict. For example, if the board of directors exercises the powers not prescribed by the legislature and makes a decision, it will become an open question regarding whether the shareholders will have the power to repeal the decision. Another question under Chinese law concerns whether the shareholders may exercise the powers provided exclusively to the board of directors. Under the current Chinese legislation, the answer to each of these questions is that the shareholders may repeal decisions of the board of directors and even exercise powers purportedly reserved exclusively to the board. To avoid unnecessary power struggles between the corporate bodies, one option is to limit the powers of the shareholders to the items prescribed by the legislature, and reserve all other managerial powers to the board of directors, while reserving all other supervisory powers to board of supervisors.

Another issue concerns the practical realities of the general meeting of the shareholders. For example, although according to written law the general meeting of shareholders is very powerful in China, in reality the meeting is often simply a rubber stamp for the wishes of the majority of shareholders. There is little or no opportunity for minority shareholders to be heard. Oppression of minority shareholders is a serious issue.

As noted by a reporter from the China Securities Daily, the meetings of shareholders can be quite boring. $\frac{129}{2}$ First, the reporter observed that there is an increasing number of inside shareholders, namely, employee shareholders, amicable to management attending the meetings, and that the number of minority shareholders and outside shareholders attending the meetings is declining. ${ }^{130}$ He cited an example of a meeting of shareholders where seven auditing reporters attended the meeting, while only six participating shareholders were in attendance. ${ }^{131}$ Second, the reporter found that the proceedings were often very mechanical -the Chair or the CEO always read the already published annual report, without adding any 
meaningful discussion regarding development, planning, the budget or management goals for the coming year. After reading the report, the Chair or CEO usually asked the shareholders to vote without offering them an opportunity to ask questions. Finally, shareholders rarely asked questions during the meetings. For instance, in five of the seven shareholder meetings audited by this reporter, no shareholder asked a single question. ${ }^{1.32}$ Moreover, the voting results were almost always $100 \%$ in favor of the resolutions proposed by management. $\frac{133}{13}$

There are several possible explanations for the inactivity of shareholders at the general meeting. In addition to factors such as time, travel expenses and inability to influence results, the main explanation may be that management appears indifferent to the concerns of minority shareholders. Some directors refuse to disclose more information than published in the annual reports, believing that they will have fewer difficulties with shareholders if they present them with minimal information. ${ }^{134}$ However, in recent years, some minority shareholders have begun taking their rights more seriously. For instance, when Shengli Co. convened its 2000 meeting of shareholders, many minority shareholders attended either personally, or sent agents or representatives. ${ }^{135}$ Fifteen hundred shareholders representing 26,260,000 shares appointed their agents to cast votes on their behalf. $\frac{136}{\text { Furthermore, at }}$ least twenty shareholders each holding fewer than 100 shares attended the meeting of shareholders. 137

In order to provide guidelines for meetings of shareholders in listed corporations, the Chines Securities Regulatory Commission (CSRC) issued the Standard Opinions on Meeting of Shareholders in Listed Corporations (Standard Opinions) on February 23, 1998, and amended it on May 18, 2000. ${ }^{138}$ This document has enhanced the Corporate Law in a number of respects. For example, the Standard Opinions recognize the minority shareholders' right to request the board of directors to hold a special meeting of shareholders. $\frac{139}{\text { If }}$ the board of directors denies the request, the qualified shareholder may notify the other shareholders and 
convene the special meeting. Unfortunately, the purpose of the Standard Opinions, as evident from inclusion of the word "opinions," in its name, is to "guide the listed corporations to convene meetings of shareholders." ${ }^{140}$ Thus, it is very difficult to classify its requirements as mandatory, or even legally binding. Given the sophisticated problems associated with the meeting of shareholders and the insufficiency of regulations governing this issue, it is necessary to further improve these rules. We therefore propose a number of amendments to the Corporate Law to address these issues.

Our first proposal is to incorporate the Standard Opinions into the Corporate Law. This would help make the requirements of the Standard Opinions and the Corporate Law consistent and coherent. After the revision of the Standard Opinions in May 2000, the first reported case of a special meeting of shareholders convened by the shareholders, instead of by the board of directors, occurred. This was the meeting of the shareholders of Xingfu Shiye Corporation. ${ }^{141}$ Mingliu Investment Limited Corporation owned 60 million of 312.8 million outstanding shares of Xingfu Shiye Corporation. After Mingliu's proposal to convene a special meeting of shareholders was denied by the board of directors, Mingliu proceeded to send out the notices and convened a special meeting of shareholders as provided by the Standard Opinions. ${ }_{142}$ Some commentators considered this a positive event because it meant that the board of directors was not the sole decision-maker regarding convention of special meetings of shareholders.

Next, shareholders should be excluded from voting on issues in which they are interested parties to curb the increasing number of interest-conflicting transactions in listed corporations, also as provided in the Standard Opinions. Current legal rules focus only on information disclosure, and make it easy for some parent corporations to allocate their profits on their business transactions with their subsidiaries. The Standard Opinions provide that "the shareholders who are the parties to the business transactions between themselves and the 
listed corporations, should not cast their votes on such transactions, and the votes held by such shareholders should not be included in the total votes represented by the shareholders at the meeting of shareholders."

Further, the shareholder's right to question management and to offer proposals should be strengthened. These two rights, alongside with the right to information, are mentioned in the Corporate Law only generally. ${ }^{145}$ To make these rules more workable, the rules should be delineate appropriate procedures for shareholders submission of proposals and requests for information.

A cumulative voting mechanism for the election of directors might also be made available to provide minority shareholders a voice in corporate governance. The current Corporate Law is silent on this point. This provision could be made optional, as is true generally throughout the United States. 146

Finally, detailed provisions should cover issues such as solicitation of proxies, the validity of voting agreements, and exceptions to the general rule of "one share, one vote" (for example, non-voting shares, multiple voting shares, corporate self-owned shares, interlocking shares, etc.). Additionally, modern telecommunication technologies, especially Internet services and video conference technologies, might be considered as alternative ways to provide for the meetings of shareholders to make it easier for the minority shareholders to participate in the corporate decision-making process. Modern telecommunication technologies could be employed alongside with the traditional face-to-face general meetings of shareholders.

\section{E. Recognition of Multiple Legal Representatives}

Both the chair of the board of directors and the CEO are statutory and indispensable corporate positions in China. The Chair holds the following statutory powers: (1) to chair the meeting of shareholders and to convene and chair the meetings of board of directors; 
(2) to examine the implementation of resolutions passed by the board of directors, $\frac{148}{(3)}$ to sign shares and bonds issued by the corporation; $\frac{149}{(4)}$ to act as the sole corporate legal representative, $\frac{150}{15}$ and (5) to exercise some powers of the board of directors under the authorization from the board when the board is not in session. ${ }^{151}$ In addition, the Chair, as a member of the board of directors, may cast one vote at the board meetings. ${ }^{1.52}$ Decisions are made by majority rule. 53

The position of the CEO can be described as follows. The CEO is an agent of the corporation and enjoys the rights conferred by the Corporate Law 154 and the corporate memorandum of associations. As an employee, the CEO enjoys the rights and interests recognized through the employment contract and by labor laws. Under the Corporate Law, the CEO takes general responsibility for daily corporate operations. $\frac{155}{5}$ Further, the CEO is hired and dismissed by the board of directors, $\frac{156}{1}$ and therefore is responsible to the board. 157

Because the Corporate Law recognizes the Chair as the sole corporate legal representative, some Chairs believe that they are the paramount corporate leaders and usurp the authority of the shareholders and directors. ${ }^{158}$ In other words, they confuse the position of legal representative recognized by the SOEs Law and that recognized by the Corporate Law. Under the SOEs Law, the manager, as the only legal representative in SOEs, not only has the authority to represent the SOEs in transactions with third parties, but also enjoys paramount decision-making and executive power. One fundamental change introduced by the Corporate Law is that managerial powers have been redistributed between several corporate bodies. The power to represent the corporation under the SOEs Law is held by the Chair of the board of directors. The general meeting of shareholders holds the most fundamental decisionmaking power. The CEO holds the detailed daily decision-making power. The board of directors holds the mid-level decision making powers. The traditional internal executive powers are divided again between board of directors and CEO. Therefore, the power 
attached to the legal representative, namely, the Chair of the board of directors, has been greatly reduced.

Under current legislation, however, the Chair is the only corporate legal representative authorized to execute contracts and other legal documents on behalf of the corporation. If other directors are required to represent the corporation in legal relationships with third parties, they must receive a special authorization from the Chair. It is thus inconvenient for a corporation to enter transactions when the legislation permits only a single legal representative. Thus, law reform should include recognition of multiple corporate legal representatives, in order to achieve transaction efficiency and to provide safeguards for third parties in the market.

\section{F. Improve the Role of the Board of Directors}

\section{The function of the board of directors}

As mentioned above, the general meeting of shareholders is intended to be the power center in corporations under the Corporate Law. This institutional arrangement may be reasonable and feasible for closely held corporations with few shareholders. However, it is time consuming, expensive, and inflexible for corporations to respond to frequent market changes and other business environments if shareholders are required to meet on every significant managerial decision. In general, in the U.S., although "all corporate powers shall be exercised by or under the authority of, and the business and affairs of the corporation managed under the direction of, its board of directors, subject to any limitation set forth in the

articles of incorporation, 159 much corporate power is delegated to senior officers. According to the U.S. Model Business Corporation Act "the management of the business of a publicly held corporation should be conducted by or under the supervision of such principal senior executives as are designated by the board of directors, and by those other executives and employees to whom the management function is delegated by the board or those executives, 
subject to the functions and powers of the board . . . "160

If China were to follow the American approach as a possible solution to the problem, the Chinese legislature would need to reallocate the powers between the meeting of shareholders and the board of directors, and thus transfer all the ordinary business managerial powers from the shareholders to the board of directors. Because the CEO also enjoys substantial managerial powers under the current Corporate Law, it is possible that there will be a conflict between the board of directors and CEO when both of them perform statutory powers. To avoid these power struggles, it is essential that the legislation define the powers of the CEO in a coherent way. Thus, the board of directors, instead of the shareholders, should become the power center in the future Chinese corporate governance, and the board should have the authority to delegate some managerial powers to the CEO or to other senior executives. The board of directors should also have the authority to supervise the performance of individual directors, the CEO and other executives.

In the U.S., committees of the board of directors, including executive committees, audit committees, nominating and compensation committees, "are assuming increasingly important

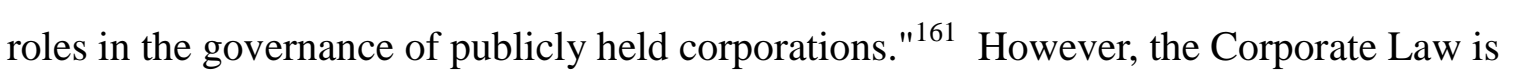
silent on whether a Chinese board of directors is authorized to appoint committees to assist the board in making informed and conscientious decisions. No Chinese corporation, except for overseas listed corporations, has reportedly appointed committees. Nevertheless, the boards of directors in overseas-listed corporations are encouraged to set up necessary professional committees with respect to matters such as strategic decision-making, auditing, and other issues, in order to improve corporate long-term development strategies. ${ }^{162}$ In light of the U.S. experience, it may be efficient to authorize boards of directors to act through committees of directors, but to also specify the nondelegable powers to be exclusively exercised by the full board in order to protect shareholders' rights from being injured by 
excessive committee powers. As the Corporate Law recognizes the board of supervisors as a comprehensive corporate body, the audit committee under the board of directors (similar to that in the U.S.), should serve under the supervision of the board of supervisors. To hold directors accountable and diligent, it may also be advisable for Corporate Law to adopt a provision similar to that of section 8.25(f) of the Model Business Corporation Act in the U.S. to provide that "the creation of, delegation of authority to, or action by a committee does not alone constitute compliance by a director with the standards of conduct." 163

\section{Independence}

In the U.S., as well as in other legal systems, outside directors play active and decisive roles in the governance of large publicly held corporations. According to a 1999 survey conducted by the Organization for Economic Cooperation and Development (OECD), the average percentage of independent directors on the board of directors is $62 \%$ in the U.S., $34 \%$ in the United Kingdom, and $29 \%$ in France. ${ }^{164}$ Corporate Law in China has no mandatory requirements for appointing outside directors in large publicly held corporations.

Since March 29, 1999, the CSRC began to require overseas-listed corporations to "increase the number of outside directors. When the board of directors concludes its term of service, outside directors should hold more than half the board seats with at least two independent directors." ${ }^{165}$ In order to prevent outside directors from becoming figureheads, the CSRC provided that "an outside director should have sufficient time and necessary knowledge to perform his/her duties. [To assist the] outside director [in] perform[ing] his/her duties, the corporation must supply [all] necessary information and materials. ${ }^{166}$ In addition to imposing qualification requirements for outside directors, the CSRC also granted substantial powers to outside directors. For instance, according the CSRC "the views of an independent director should be specified in the board resolution." Moreover, a related transaction of the corporation may not take effect until approved by an independent director. 
Two or more independent directors may propose that the board of directors call for a special meeting of shareholders. Independent directors may directly report to the meeting of shareholders, the CSRC and other relevant agencies. $\frac{167}{167}$

These CSRC requirements apply only to overseas-listed corporations. As far as domestically-listed corporations are concerned, the Guidelines on Memorandum of Associations in Listed Corporations provides an optional article according to which "the listed corporations may appoint independent directors when it deems it necessary." 168 However, it has no requirement for a minimum number of outside directors, nor requirements regarding their duties. In October, 2000, the State Committee of Economy and Trade permitted SOE-corporatized corporations to "have independent directors, who are

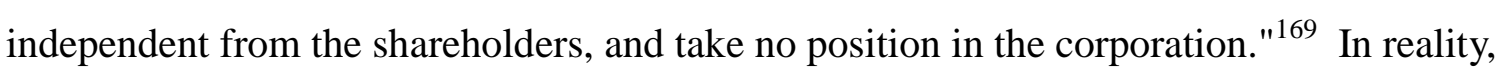
some listed corporations voluntarily elect some independent scholars to serve as independent and outside directors, and encourage them to play active roles. For example, in Xiao Tian'e Corporation, six out of the twelve members of the board are independent directors, and three directors may act together to veto board resolutions.

However, many independent directors find it difficult to exert any substantial influence, other than symbolic, with the board. ${ }^{171}$ According to a senior Chinese economist and a former independent director in Lanzhou-based Huanghe Co., the independent outside directors are dispensable, and they only play a very limited role on the boards of most listed corporations in China. ${ }^{172}$ This former director personally served as an independent director for approximately only six months in Lanzhou-based Huanghe Co. ${ }^{173}$ When the Chair and the CEO of the company ran into serious confrontations, the independent outside directors could not function, and this director felt he had no choice but to resign. 174 Moreover, during his six months of service, he only had one opportunity to attend the meeting of board of directors. 
The indispensable position of outside and independent directors in listed corporations should be recognized by the Corporate Law on a mandatory basis. In order to provide outside directors with stronger powers, the legislature should determine a statutory minimum percentage of independent and outside directors in listed corporations. Nevertheless, a significant challenge will be balancing the need to encourage independent directors to play a more significant role in listed corporations while avoiding corruption. For this purpose, both sufficient remuneration and enforcement of legal duties are essential for independent directors.

\section{G. Provide Restraint and Incentive Mechanisms for Directors and Executives}

Unfortunately, in Chinese SOEs and SOE-corporatized corporations, it is common for directors and executives to misuse their powers and to seek personal gain, or to even seize corporate property. $\frac{176}{10}$ For instance, some SOE directors and managers control the power to appoint and dismiss treasurers, and therefore have the means to force treasurers to keep several different accounting books for fraudulent purposes. ${ }^{177}$ For example, in one case, some perfect machines were sold as steel rubbish, while the corporation purchased more raw materials than it could use in the next several hundred years. ${ }^{178}$ Some directors and executives made great personal profits during the process of corporate asset restructuring. 179

In one typical case, a former CEO of Anqing Paper Industry Corporation decided to establish three branches of the corporation, costing the corporation approximately $\$ 1,000,000$, although no profit was generated. ${ }^{180}$ He also invested over $\$ 1,000,000$ in technology innovation, but the company has yet to produce a qualified product. ${ }^{181}$ In addition, he also entered into a purchase of waste paper for the corporation from someone with whom he had a personal relationship, at an extremely high price. 182

Some SOE officers behave appropriately during most of the SOE life, but become corrupted just before their retirement. ${ }^{183}$ Because many corrupted directors and executives 
are approximately fifty-nine years old, their "sunset misbehavior" is referred to as the

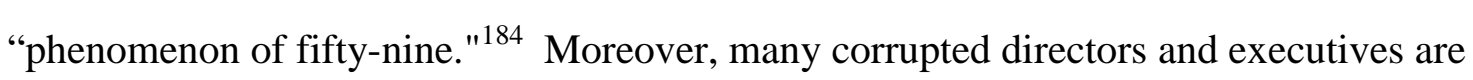
famous figures, and serve in several leadership positions at the same time, including Chair, CEO, secretary of the Communist Party Committee, chief of government agencies, etc. ${ }^{85}$ In some SOEs, the Chairs and CEOs hold supreme managerial power, and other corporate bodies are unable to successfully challenge their authority. 186

The irresponsibility of directors and executives has resulted in insolvency or bankruptcy of many SOEs. A survey conducted by the Anhui Province authorities in 1997 revealed that directors and executives were responsible for more than half of the insolvency or bankruptcy cases in 110 SOEs. ${ }^{187}$ In addition, many managers in SOEs and SOE-corporatized corporations are unhappy with their current situation. In the Confederation of Enterprises Survey, $83 \%$ of the respondent managers said that the biggest obstacle for the growth of first rate of directors and executives in China is the lack of an effective incentive and disciplinary mechanism; and $77 \%$ of them prefer more generous annual salary as the major form of their

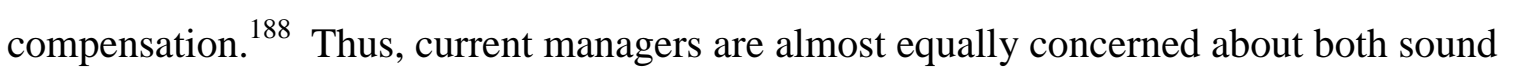
incentives and disciplinary rules for Chinese directors and executives.

\section{Accountability}

In the U.S., directors and officers are deemed fiduciaries of the corporation because their relationship with the corporation and its shareholders is one of trust and confidence. As fiduciaries, directors and officers owe and legal duties to the corporation and the shareholders. These fiduciary duties include the duty of care and the duty of loyalty, $\frac{189}{\text { and }}$ directors and officers are held personally accountable for breach of these duties. In contract, in the Chinese traditional planned economy, the legislation was silent with respect to the duties and obligations of directors and executives. It has been common for directors and executives who have caused damage to one enterprise, to be appointed by government 


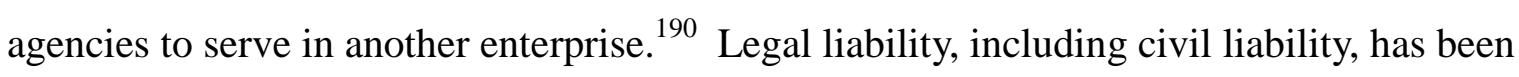
rarely imposed on wrongdoers or corrupted directors and executives.

In light of the significant deficiencies in the traditional governance structure of SOEs, the Corporate Law provided for a number of provisions relating to the duties of directors, supervisors and officers. ${ }^{191}$ It also introduced some provisions dealing with the legal liabilities against them, including civil, criminal and administrative liabilities. 192

Unfortunately, the Chinese Corporate Law is silent on the director's duty of care, and does not provide a workable test for monitoring directors' performance. In order to curb the incidents of misuse of corporate powers, it is necessary to employ mechanisms to hold the management of SOEs accountable for their behavior. China might therefore consider the U.S. approach to the duty of care and require directors and officers to exercise the degree of care in accordance with the knowledge, diligence and experience expected from an ordinarily prudent director in a similar position, and under similar circumstances, and hold them personally accountable if the fail to do so. 193

The governing corporate bodies should assert claims whenever the corporate interest is damaged or threatened by directors or executives' breach of duties. However, it is possible that the board of directors may refuse or fail to do so due to the amicable relationships between the wrongdoing directors and the remaining directors. The same phenomenon may occur with respect to the board of supervisors, when some supervisors are close friends of the wrongdoing director.

In the U.S., shareholders have a right, under certain circumstances, to bring a derivative action when the corporation suffers a wrong not redressed by the corporate directors. $\frac{194}{1 .}$ Influenced by the U.S. experience, Japan introduced derivative actions in 1950, with

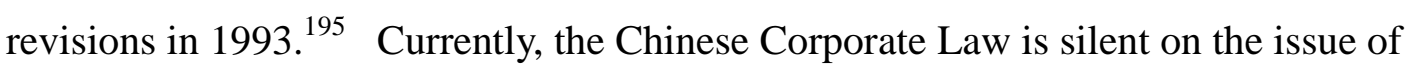
shareholder derivative suits. However, this silence has not prevented the Chinese courts from 
hearing shareholders' derivative actions.

Nevertheless, Chinese shareholders are not very active in pursuing derivative actions. If China wishes to make derivative actions available to shareholders to provide a check on managerial abuse, it is necessary that the Chinese legislature provide some clear procedural rules.

\section{Compensation}

One of the most serious problems with corporate governance in China is that many directors and executives are underpaid. In the forty-nine published annual reports of listed corporations for the financial year of 1998, forty-five listed corporations reported the salary of their directors and senior executives. ${ }^{196}$ According to the report, $47 \%$ of the directors and senior executives received annual compensation below RMB 30,000 Yuan (about US\$ 3,500), 29\% received annual compensation ranging from RMB 30,000 Yuan (about US\$ 3,500) to RMB 50,000 Yuan (about US\$ 6,000), $13 \%$ earned annual compensation ranging from RMB 50,000 Yuan (about US\$ 6,000) to RMB 100,000 Yuan (about US\$ 12,000), and $11 \%$ received over RMB 100,000 Yuan (about US\$12,000) of annual compensation. For instance, the Chair of the board of directors of China Light Motor Group Co. earned 40,000 Yuan (about US\$ 4,500) as annual compensation in 1998, while his corporation sold 1.5 million motorcycles that year. The chair of another corporation, Houjian, earned only RMB 39,000 Yuan (about US\$ 4,400) as annual compensation in 1998, while his corporation sold RMB 8.2 billion (about US\$ 1 billion) of products that year. ${ }^{197}$

Since many Chinese directors and executives are underpaid, some of them are tempted to seek illegal income. Unreasonable compensation is likely to be one of the major reasons for the "phenomenon of fifty-nine." For instance, the former Chair and CEO of Hongta Tobacco Corporation, embezzled US\$1.7 million in corporate funds. His total lawful compensation during the seventeen years of serving his corporation was RMB 800,000 Yuan (about 
US\$96,000), while the corporation made profits of RMB 80 billion Yuan (about US\$9.6 billion). In other words, his lawful income accounted for a mere 0.001 percentage of the total corporation's income. 198

It is essential to improve the compensation mechanism for directors and executives. To help attain this objective, innovative compensation mechanisms, such as stock option programs, might be made available to directors and executives in most SOE-corporatized corporations. In spite of their adoption by foreign-invested enterprises in China, stock option programs are relatively new to many SOEs and SOE-corporatized corporations. In Beijing, ten enterprises have been attempting to implement the stock option contract system, including Bofei Instrument-Making Corporation, Beijing Switch Gear Share-holding Limited Corporation, Tongzhou Subsidiary Corporation of Tongrentang, Shuangqiao Pharmaceutical Factory, Zhongguancun Real Estate Corporation, and Caishikou Department Store. ${ }^{199}$ Among these corporations, Zhongguancun Real Estate Corporation and Caishikou Department Store have recently cancelled the project because their managers were concerned about their value.

According to a typical stock ownership plan, SOE managers receive a certain amount of stocks in installments at a fixed price during their tenure and can earn profits on these stocks in the future. ${ }^{01}$ The managers must reinvest the profits in the enterprise by transferring them into new shares during the first three years. ${ }^{202}$ The managers are also responsible for losses incurred during that period. ${ }^{203}$ Only after the managers' performance is considered satisfactory, may they cash in their stocks or reinvest the profits in the enterprise two years after they leave the post. ${ }^{204}$ Shanghai also carried out a trial reform rewarding senior executives of enterprises with stock options. "Directors of listed corporations, are given a certain number of shares, but they can only be cashed in years later, sometimes even after their retirement. Passing a strict and comprehensive long-term assessment of the director's 
working performance is the prerequisite for obtaining the reward."

Stock option programs should be implemented nationwide. The legislature should offer guidelines for the content and validity of stock option contracts. For example, the legislature should provide guidelines on methods for determining proper rewards. Relatively moderate rewards may be unattractive to the directors and executives, while overly generous ones may be unfair to shareholders and employees. In assessing the performance of directors and executives, strong supervision is also necessary to ensure the objectivity and impartiality of the appraisal process.

\section{H. Improve the Role of the Board of Supervisors}

The board of supervisors is an indispensable corporate body in the Chinese corporate governance structure. Pursuant to the Corporate Law, the supervisors shall perform the following duties: (1) examine the corporate financial affairs; (2) supervise directors and executives' breaches of statutes or memorandum of associations in performing their duties; (3) demand directors and executives to redress their misconduct damaging the corporate interest; (4) propose special meetings of the shareholders; and (5) other duties as stipulated in memorandum of associations. Supervisors also have the power to audit the meeting of board of directors. 206 The board of supervisors includes shareholder representatives and certain employee representatives, with the percentage of representation of each group to be stipulated in the memorandum of association. The employee representatives are elected by the corporate employees in democratic elections. ${ }^{207}$ In order to secure the impartiality of supervisors, "directors, executives or financial officers may not concurrently serve as supervisors. $" 208$

As an efficient watchdog for the corporation and shareholders, the board of supervisors should obtain meaningful tools for confronting problems associated with insider control. However, the current supervisory mechanism is generally incapable of identifying and 
addressing managerial corruption. As a survey conducted by State Committee of Economy and Trade indicated, some SOE-corporatized corporations have no boards of supervisors, and one-third of those with boards of supervisors have difficulties performing their supervisory duties. ${ }^{209}$ In the absence of meaningful supervisory mechanisms, many SOE-corporatized corporations have been faced with serious problems of corruption. ${ }^{210}$ For instance, hundreds of millions of dollars of corporate funds were misused by the senior executives in Zhengzhou Baiwen Corporation in Henan Province. ${ }^{211}$ Therefore, further legislative reform with respect to rules governing the board of directors is necessary.

First, having outside supervisors in the board of supervisors should be mandatory for large publicly held corporations. To achieve impartial supervision, the supervisors should be completely independent from the directors and executives. Supervisors should have strong expertise in essential matters, such as corporate management, corporate finance or business law.

Second, the powers possessed by the board of supervisors should be redefined. The current supervisory powers recognized by the Corporate Law are of a postmortem and passive nature. To enable supervisors to obtain relevant and crucial information, the board of directors should be obligated to report to the board of supervisors on a regular basis. Moreover, the board of supervisors should have authority to take legal actions against directors or executives on behalf of the corporation. The board of supervisors should become a corporate body between the shareholders and the board of directors in the corporate hierarchy, and should hold the power to appoint and dismiss directors. The board of supervisors should also hold statutory decision-making powers with respect to fundamental investment decisions or transaction plans. In addition to comprehensive supervision over managerial activity, the board of supervisors should be required to supervise the financial and accounting activities. In order to fulfill their obligations, the board of supervisors should be 
permitted to employ outside advisers, such as lawyers, auditors, and accountants.

In order to strengthen the State shareholder's supervision of SOEs, the State has begun to send special inspectors to supervise traditional SOEs and SOE-corporatized corporations. 12 The State Council appointed the first group of twenty-one special inspectors to large SOEs on

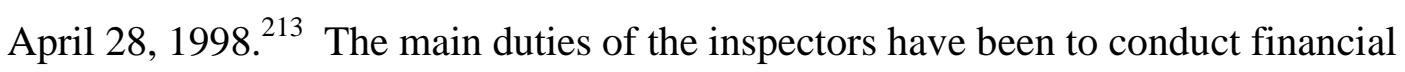
supervision of enterprise operations on behalf of the State, and evaluate the senior executives' performance in terms of legality and administrative capability. The inspectors have not been involved in the production or management of the enterprises. Vice-minister level officers are qualified to serve as special inspectors. Each inspector has four special assistants, which are chosen from officials with professional backgrounds in banking, finance, personnel, auditing and supervisory bodies, and macro-control agencies. The inspector and the four assistants form a special inspector's office, and are generally responsible for supervising five enterprises. The term of office for a special inspector and assistants is three years, and they may not serve a second term in the same enterprise. Members of the special inspector's office cannot hold a position in the enterprise they supervise, and may not accept any compensation, benefits, entertainment or gifts from the enterprise. 214

The inspectors have been very harsh in supervising and investigating the management of their supervised corporations. We propose that special inspectors should be replaced by the board of supervisors in the future. There is no need to have both supervisory authorities, provided that the board of supervisors actually functions as a supervisory body.

\section{The State as a Shareholder}

In China, the State acts as a majority shareholder in many listed corporations. ${ }^{215}$ This situation will probably remain unchanged in the near future. State shareholder status may trigger a number of conflicts of interest -- on the one hand, the government may be concerned about whether the State is sufficiently protected as a shareholder of the enterprise, and on the 
other hand, minority shareholders and potential investors may be concerned about potential misuse of the controlling shareholder position by the State. ${ }^{216}$ Both concerns are understandable. Protective and restrictive mechanisms are, therefore, indispensable with respect to the State shareholder.

\section{Conceptual orientation: differentiating the State shareholders' rights from}

\section{traditional property ownership}

There are three basic forms of State ownership in China: (1) traditional property ownership; (2) creditor's rights; and (3) shareholder's rights. Upon corporatization of SOEs, the State's property ownership over SOEs is that of a shareholder. As a shareholder, the State may not directly control, utilize or dispose corporate property. The State shareholder may exercise its right to dividends and net assets, the right to governance participation, and other shareholder rights.

When the State owns a large portion of the shares of SOE-corporatized corporations, it is very easy for the State (or the State agent) to exercise dominant influence on the corporation. The China Confederation of Enterprises Survey showed that "61.33\% of respondent managers say that government and corporations need to be further separated, [and] $59.67 \%$ of respondent managers say that the establishment and duties of State shareholder's agents need

further improvement. "217 As a feasible investment policy for State shareholders, shares held by the State exceeding a certain percentage might be required to be held as non-voting preference shares. Non-voting preference shares may be very helpful in preventing the State shareholder from misusing its controlling position yet ensure the State's right to dividends and net assets.

To facilitate the relationship between SOE-corporatized corporations and the State shareholder, it is essential for the State shareholder to respect corporate property rights. The Corporate Law provides that "a corporation, as a legal person, shall enjoy corporate property 
rights regarding all the properties formed by the shareholders' investments, and possess civil rights and bear the civil liabilities in accordance with the law." ${ }^{218}$ The language "corporate property rights" was introduced for the first time in China by the Corporate Law.

The Corporate Law also states that "the ownership of State-owned assets in a corporation shall vest in the State. ${ }^{, 219}$ This statement is imprecise, or even misleading, because it ignores the difference between shareholders' rights and corporate property ownership. However, the Corporate Law also states that "a corporation shall, with all its corporate assets, operate independently and be responsible for its own profits and losses according to law. A corporation shall, under the macro-adjustment and control of the State, organize its production and operation independently in accordance with market demand for the purpose of raising economic benefits and labor productivity, maintaining and increasing the value of its assets." ${ }_{220}$ This provision implies that the above-mentioned clause regarding vesting of Stateowned assets was included in the Corporate Law to confirm the shareholder's rights enjoyed by the State -- not to permit the State to take away the corporate property rights of the corporation. 221

\section{The limited scope of wholly State-owned corporations}

In China, "the State economy is over-distributed, with its overall quality not so high, and the distribution of resources is not reasonable enough, a situation which must be tackled with great effort." ${ }_{22}^{22}$ Many Chinese SOE managers therefore prefer that SOEs withdraw from competitive industries. The Confederation of Enterprises Survey found that "81.29\% of respondents prefer that the SOE withdraw from general competitive industries, $16.22 \%$ do not believe that the SOEs should withdraw from general competitive industries, and $1.87 \%$ prefer that SOEs withdraw even from the monopoly industries of the national economy, the people's livelihood and the national defense."223 Thus, most respondents support the idea that in competitive industries SOEs should be corporatized into corporations with multiple 
shareholders. This trend may help reduce the State's investment risks, and create more investment opportunities to private investors. With respect to the question of the most suitable shareholder structure for SOE corporatized corporations, "63.88\% of respondents prefer multiple shareholders, $22.55 \%$ prefer State-invested corporation as the majority shareholder, $7.1 \%$ prefer State as the majority shareholder, $6.47 \%$ prefer private shareholders, and $55.35 \%$ prefer most medium-sized and small SOEs to be transferred to individuals or partners."224

The Chinese government also endorses the strategy of developing sound corporate governance by encouraging multiple shareholder structures in SOE-corporatized corporations. "Diversity of equities is conducive to the formation of a standardized corporate governance. It is necessary to develop corporations featuring multiple investing entities, except for a small number of enterprises that should be monopolized by the State."225 Nevertheless, some SOEs have been restructured into wholly State-owned corporations. 226 One reason is that SOE managers prefer to maintain the traditional governance structure and government agencies prefer to maintain traditional control over wholly State-owned corporations. Another reason is the misinterpretation of the second paragraph of Article 64 of Corporate Law 227 which provides that "corporations manufacturing special products determined by the State Council, or corporations belonging to the category of specialized industries, shall take the form of wholly State-owned corporations." 228

The wholly State-owned corporation form should be restricted exclusively to industries promoting national and public interests, while all other SOEs should be transformed into corporations with more than one shareholder, or to publicly held corporations, including listed corporations. To pursue this goal, it is necessary to relinquish the existing quota control regarding initial public offerings in the Chinese securities market, and allow all corporations satisfying the statutory listing requirements to be listed at the securities exchanges. ${ }_{229}$ The 
general principles and regulations governing the legal relationships between common shareholders should be equally applicable to the relationship between State-shareholder and other shareholders.

\section{Parent-Subsidiary Control}

The corporate bodies of some SOE subsidiaries are under the direct control of their parent corporation. In response to this problem, the CSRC requires listed corporations to be independent from their parent corporations in terms of "independent personnel (renyuan duli), independent assets (zichan wanzheng) and independent finance (caiwu duli). "230 However, "the three separation requirements are insufficient especially with respect to listed corporations with highly concentrated share-holding and listed corporations in the industries

of steel, petrochemical and power." and their parent corporations have caused serious problems for some of the creditors and the minority shareholders of these corporations. For instance, the 1999 annual report of Daqing Lianyi Co. revealed that the largest majority shareholder stole RMB 620 million Yuan from this corporation, accounting for $50 \%$ its total corporate assets.

There are many reasons for the excessively close connections between listed corporations and their parent corporations. First, the shareholding structure of listed corporations is not diverse enough to prevent parent corporations from firmly controlling key decisions in their subsidiaries, including personnel decisions. In contrast, corporations with a highly diversified shareholding structure have clearer boundaries between their parent corporations. Examples of corporations that clearly respect the boundaries between parents and subsidiaries include Shenwanke, 233 Aishi Gufen, 34 and Fangzheng Keji. 35

Second, to reduce the transaction costs, some listed corporations would like to rely on the procuring and marketing networks established by their parent corporations. ${ }^{236}$ Third, some listed corporations intentionally conduct business transactions with their parent corporations 
to present "satisfied profits." Fourth, most listed corporations were formally separated from their parent corporations when they initially incorporated, but have always acted as small factories or small parts in the broader framework of the parent corporations. Thus, the parent corporations regard the listed corporations as small isolated islands surrounded by the parent corporations. ${ }^{237}$ Fifth, some powerful executives act as Chair, CEO and Party Committee Secretary in both the subsidiary and the parent corporation. Their dual positions make it impossible to separate the listed corporations from their parent corporations. ${ }^{238}$ Further, many people argue that "the separation between the listed corporations and the parent corporations will be a long and hard process" 39 and thus "the excessive connections between them will not be fundamentally changed in the near future." ${ }^{240}$ Yet, although Chinese legislation does not recognize veil-piercing theory, the doctrine of piercing the corporate veil might be imposed to hold the parent corporation accountable for the debts of the subsidiary in cases where the corporate boundaries are not respected. 241

\section{Transferability of State-owned shares}

At the present time, there are various classifications of shares in Chinese listed corporations. Some shares are transferable $e^{242}$ while others, including those owned by the State, are not. As indicated in Table 1 below, the total nontransferable equity of listed corporations was 166.484 billion shares, accounting for $65.89 \%$ of the total equity of listed corporations by the end of 1998, including 86.551 billion shares owned by government, 71.617 billion shares owned by legal persons, 4 and 8.317 billion shares owned by employees and others. Outstanding transferable shares amounted to 86.193 billion shares, but consisted of only $34.11 \%$ of the total equity of listed corporations. The transferable shares included 60.803 billion A shares, 13.395 billion B Shares and 11.995 billion $\mathrm{H}$ shares. ${ }^{244}$ In 1999, the transferable shares increased slightly. Among the 260 billion shares of the total equity of the listed corporations, there are about 185 billion transferable, which 
William Davidson Institute Working Paper 407

accounted for $71.15 \%$ of the total equity of the listed corporations. About $90 \%$ of the

nonnegotiable shares are State-owned shares and State-owned legal persons' shares. 245 
Table 1

Share Structure of Listed Corporations As of 12/31/98

\begin{tabular}{|c|c|}
\hline$\bullet$ & No. of Shares (100MM) \\
\hline 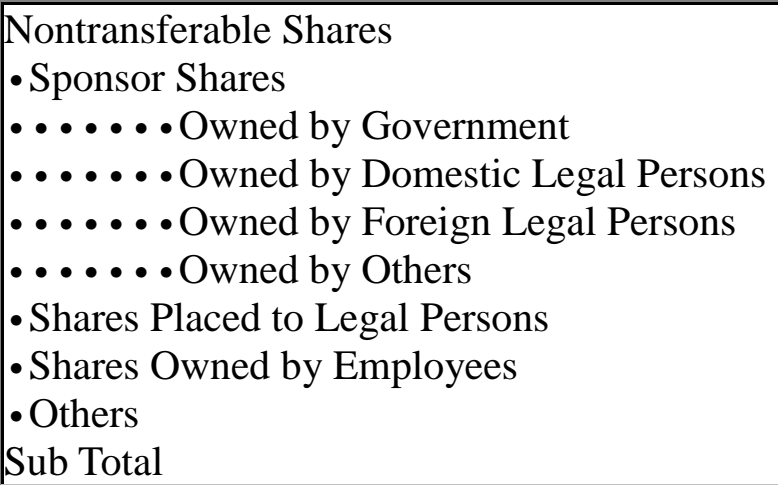 & \begin{tabular}{|l}
$1,429.33$ \\
865.51 \\
528.06 \\
35.77 \\
0.00 \\
152.34 \\
51.70 \\
31.47 \\
$1,664.84$
\end{tabular} \\
\hline $\begin{array}{l}\text { Tradable Shares } \\
\text { - A Shares } \\
\text { - B Shares } \\
\text { - H Shares } \\
\text { - Others } \\
\text { Sub Total }\end{array}$ & $\begin{array}{l}608.03 \\
133.95 \\
119.95 \\
0.00 \\
861.93\end{array}$ \\
\hline Total & $2,526.77$ \\
\hline
\end{tabular}

The non-transferability of State shares is proving detrimental to the growth of Chinese securities market and devalues the State's shareholdings. Given that only one third of the total shares of the listed corporations are tradable, State shares should be freely tradable. This should not only benefit the State shareholder, but also fundamentally stabilize the excessively speculative stock market in China. In 1999, as a first bold step, the Ministry of Finance permitted the State-owned shares to be reduced to $51 \% .247$ This is a welcome step.

\section{Conclusion}

The first Chinese Corporation Law was enacted in January, 1904 during the late Qing Dynasty. When the new China was founded in 1949, business corporations gradually disappeared. This was due to importation of the highly centralized economy model from former Soviet Union. In the late 1970s, China started to introduce a market economy, SOEs were redefined as business corporations, and private corporations were incorporated.

Among other things, the traditional Chinese SOE governance system was one of the 
major built-in institutional obstacles hindering profit-maximization at enterprise levels. In the period of the planned economy, SOEs were treated as a branch of government, and enterprise governance was nothing more than a part of the general system of government. The purpose of SOEs was thus to fulfill the production plans of the government agencies, not profit-maximization. SOE managers became accountable to government agencies rather than the market. The SOE leaders were in essence like government officials in terms of their responsibility toward their supervising government agencies, their official ranking and their promotion.

The traditional enterprise governance regime is not compatible with the market economy China is in the midst of developing. For instance, most traditional SOE leaders are likely to be loyal to their supervising government agencies and lack the expertise and experience needed to operate the SOE business in a competitive environment. The transition from the planned economy to a market economy requires reformation of the composition and function of SOE governance.

Chinese policy and lawmakers have been struggling in their efforts to determine the optimal corporate governance model for Chinese SOEs. At first, Chinese SOEs were granted more autonomous powers, and SOE leaders were given more authority to manage SOEs with a view toward profit maximization. These legislative objectives are reflected in the SOE Law of $1988^{248}$ and implementing regulations of 1992.49 However, with the general manager as the paramount leader without any meaningful checks and balances from other interest groups within the SOE governance structure, it is not surprising that these leaders began to misuse their power. Compared with the traditional governance structure of SOEs in the period of the planned economy, the transitional governance structure of SOEs was even worse. The transitional SOE leaders had more managerial powers than their predecessors in traditional SOEs, as well as more resources, thus facilitating embezzlement and misuse. Moreover, this 
period also included unnecessary and excessive government interventions. In addition, governmental agencies did not understand that their role as a shareholder of a business corporation was different than their role as a governmental agency. There was also no predictable or feasible institutional norms established to govern the relationship among governmental agencies, SOE leaders and other constituencies such as employees. In short, the transitional governance structure represented a creative yet unsuccessful effort to restructure the SOE governance regime.

In addition to frequently reported managerial corruption, the SOE governance regime was also marked by unsatisfactory financial performance. As indicated in a report of the China Enterprise Evaluation Association, the efficiency of China's top 500 industrial enterprises was much lower than the top 500 global companies. ${ }^{250}$ The average ratio of profits to assets of the Chinese enterprises was $2.78 \%$, compared to $11.29 \%$ for global companies in $1988 . \frac{251}{2}$ The per capita income for Chinese enterprises was US\$27,456 while their global counterparts enjoyed per capita income of US\$288,855 during the same period. In another example, the average total assets and sales revenues of China's top 500 industrial enterprises in 1998 was US\$711.6 million and US\$398.1 million respectively, accounting for

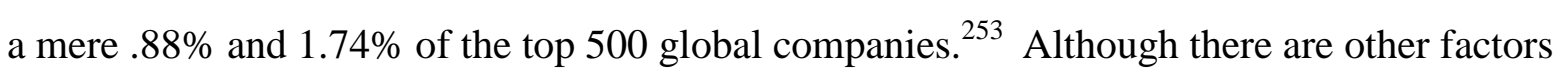
contributing to this poor financial performance of SOEs, unsuccessful SOE governance played a substantially negative role.

In light of the shortcomings with both its traditional and transitional governance structures, China has begun to look to the successful corporate governance role models in market economies and has thus begun implementing some common corporate governance norms (including general meeting of shareholders, board of directors and board of supervisors). In his government working report before the NPC on March 5, 2000, Premier Zhu Rongji promised that the "Chinese government will actively encourage multinational 
corporations to participate [in] the restructuring and transformation of SOEs."254

Multinational corporations will be able to acquire State shares in the future. More liberalized

policies are expected to attract foreign investors to enter the Chinese securities market after

China enters the WTO.

Corporatization reform will not, however, be successful without sound corporate

governance. It is necessary for Chinese policy makers to consider the corporate governance

structure as the core of the corporate system, and clarify the duties of the various corporate

actors such as the shareholders, the board of directors, the board of supervisors and the

executives. $\frac{255}{\text { It }}$ is hoped that by eliminating excessive governmental control, ensuring the

government's interest as an investor, and effectively holding the management accountable,

Chinese SOEs will become more successful and attractive to foreign investment.

Good corporate governance in China, however, will not result from merely changes in

the Corporate or Securities Laws. Good corporate governance will also depend heavily upon

successful reform of government agencies and the legal system.

\footnotetext{
${ }^{1}$ For instance, in May 1999, the Organization for Economic Cooperation and Development (OECD) Ministers adopted the OECD Principles of Corporate Governance, with the support of the G7 member governments, international organizations, the private sector, as well as the OECD's Business and Industry Advisory Committee and its Trade Union Advisory Committee. The G7 member governments include France, the United States, Britain, Germany, Japan, Italy, and Canada. The G7 or "Group of Seven" industrialized nations have been meeting annually since 1975 to deal with the major economic and political issues facing their domestic societies and the international community as a whole. The 1997 Denver Summit saw full Russian participation in all but financial and certain economic discussions; and the 1998 Birmingham Summit saw full Russian participation, giving birth to the G8. For more information see http://www.g7.utoronto.ca/g7/what is g $\mathrm{g} 7 . \mathrm{html}$ [Visited on 10-8-01]. These non-binding Principles are intended to serve as a reference point for countries' efforts to evaluate and improve their own legal, institutional and regulatory framework. In June, 2000, the OECD launched the OECD Steering Group, whose role is to guide the work on Corporate Governance. In the context of cooperation between the OECD/World Bank, the OECD is also taking the lead in establishing a set of Regional Corporate Governance Roundtables. The Roundtables provide a framework for policy dialogue and multilateral exchange of experience between public and private sector experts. Four Regional Roundtables have already been established in Asia, Eurasia, Latin America and Russia. See http://www.oecd.org/daf/corporateaffairs/governance/. [Visited on 9-14-01].

For further discussion of other various issues of global corporate governance, see, e.g., Lawrence A. Cunningham, Commonalities and Prescriptions in the Vertical Dimension of Global Corporate Governance, 84 CORNELL L. REV. 1133 (July 1999) (explaining traditional models of corporate governance and models for global corporate governance); Eileen M. Filliben \& Michael D. Goldman, Corporate Governance: Current Trends and Likely Developments for the Twenty-First Century, 25 DEL. J. CORP. L. 683 (2000) (discussing current trends in corporate governance and theorizes on the likely impact of those trends for the twenty-first century); Bernard Grossfeld, Loss of Distance: Global Corporate Actors and Global Corporate GovernanceInternet v. Geography, 34 INT'L LAW. 963 (Fall 2000) (discussing the effect of the Internet on global corporate actors and the importance of global corporate governance systems); Craig LaChance, Nature v. Nurture:
} 
Evolution, Path Dependence and Corporate Governance, 18 ARIZ. J. INT'L \& COMP. L. 279 (Spring 2001) (examines the last seventy years of corporate governance and discusses where corporate governance is headed); Amir N. Licht, The Mother of All Path Dependencies Toward A Cross-Cultural Theory of Corporate Governance ystems, 26 DEL. J. CORP. L. 147 (2001) (discusses the growing awareness of the relevancy of national culture to corporate governance and introduces a framework for analyzing problems).

${ }^{2}$ In addition to differences in corporate governance regimes existing between developing and developed countries, differences also exist among developed countries. For instance, the U.S., Germany and Japan each has its own institutional features regarding corporate governance. See, e.g., Michael Bradley, Cindy A. Schipani, Anant K. Sundaram \& James P. Walsh, The Purposes and Accountability of the Corporation in Contemporary Society: Corporate Governance at a Crossroads, 62 LAW \& CONTEMP. PROBS. 10, 50-77 (Summer 1999); Timothy L. Fort \& Cindy A. Schipani, Corporate Governance in a Global Environment: The Search for the Best of All Worlds, 33 VANDERBILT J. TRANSNATIONAL L. 829, 842 -58 (2000). See also Brian R. Cheffins, Current Trends in Corporate Governance: Going From London to Milan Via Toronto, 10 DUKE J. COMP. \& INT'L L. 5 (Fall/Winter 1999) (discusses whether governance reforms in Canada are suitable for similar reforms in the United Kingdom and Italy); John H. Farrar, The New Financial Architecture and Effective Corporate Governance, 33 INT'L LAW. 927 (Winter 1999) (discusses the impact of globalization on corporate governance and national corporate laws); Craig Ehrlich Dae-Seob Kang, U.S. Style Corporate Governance in Korea's Largest Companies, 18 UCLA PAC. BASIN L. J. 1 (Fall 2000) (looks at the history of corporate governance in the United States and Korea, and then discusses the reforms that have been instituted or recommended in Korea over the past three years).

322 U.S.C. § 6901; H.R.4444 Public Law No: 106-286, entitled "To authorize extension of nondiscriminatory treatment (normal trade relations treatment) to the People's Republic of China, and to establish a framework for relations between the United States and the People's Republic of China. Authorize extension of nondiscriminatory treatment (normal trade relations treatment) to the People's Republic of China."

See http://thomas.loc.gov/cgi-bin/bdquery/z?d106:HR04444:@@@L\&summ2=m\&. [Visited on 9-14-01]

For details regarding PNTR issues, see also: http://www.uschina.org/public/wto/archive.html\#pntr. [Visited on 9-14-01] For coverage by the Chinese media, see Agencies, Clinton Signs China Bill, Sends Barshefsky for Crucial Talks, CHINA DAILY, Oct. 11, 2000.

${ }^{4}$ China is one of the founding members of the General Agreement on Trade and Tariffs (GATT), which was succeeded by the World Trade Organization (WTO). See General Agreement on Trade and Tariffs: Final Act Embodying the Results of the Uruguay Round of Trade Negotiations, opened for signature Apr. 15, 1994, 33 I.L.M. 1125 art. III, at 1145 (1994). Now, as the world's tenth largest trading country, China seeks to enter the world trade body. See < http://www1.chinadaily.com.cn/highlights/wto.html>. According to Shi Guangsheng, minister of foreign trade and economic cooperation, China has been working to join the organization at the earliest possible date. China has virtually completed all bilateral negotiations with other member economies, although there are still several unresolved issues such as the implementation of agreements on agriculture and industrial subsidies and market accession to certain service trades. See Xinhua, Trade Minister: China's Stance on WTO Accession Unchanged, CHINA DAILY, Mar. 13, 2001.

${ }^{5}$ For a discussion of the possible benefits (including investment opportunities) to inure to the United States by China's WTO entry, see sources cited at <http://www.uschina.org/public/wto/archive.html\#pntr>. [Visited on 914-01]

${ }^{6}$ State ownership was considered the highest form of public ownership and the goal of socialism. To secure State ownership, different levels of legal validity were granted to different types of ownership. In other words, the State ownership is superior to collective ownership, which is superior again to individual ownership. The rationale was to diminish the threat to State ownership from the private sectors.

${ }^{7}$ For instance, Article 11 of Chinese Constitution of 1982 provided only the existence of self-employed businesses, but not the existence of private businesses. On April 12, 2001, the NPC amended this Article to allow the existence and development of private businesses. However, this recognition carried some restrictions, as this amendment only considered as private businesses those that supplemented the socialist public-sector economy. These restrictions were lifted after amendment of the Chinese Constitution in 1999. The amendments updated Article 6 of Chinese Constitution of 1982 to read as follows: "In the primary stage of socialism, China should uphold the basic economic system in which public ownership is dominant and diverse forms of ownership develop side by side. It should also uphold the distribution system with distribution according to work remaining dominant and with a variety of modes of distribution coexisting." This article supports the development of the non-State sector. The terms of Article 6 are reinforced by changes made to Article 11 of Chinese Constitution of 1982 that states: "the non-public sector, including self-employed and private businesses, within the domain stipulated by law, is an important component of China's socialist market economy. China should protect the legitimate rights and interests of the self-employed and private enterprises, and China should also exercise guidance, supervision and management over them in accordance with the law." 
See Zhonghua Renmin Gongheguo Xianfa Xiuzheng An (Amendments to the Constitution of People's Republic of China), passed by the NPC on March 15, 1999.

${ }^{8}$ The traditional SOEs in the period of the planned economy were not regarded as independent legal persons. This is why the Decision of the Central Committee of Chinese Communist Party on Several Issues Concerning the Reform of Economic System of 1984 found it necessary to offer a lengthy explanation on why traditional SOEs should become legal persons and gain more managerial powers to make them more competitive. See Zhonggong Zhongyang Guanyu Jingji Tizhi Gaige De Jueding (The Decision of the Central Committee of Chinese Communist Party on Several Issues Concerning the Reform of Economic System), RENMIN ChubAnshe (PeOPLE's PRESS), 1984. The phrase "legal person" became a popular phrase associated with SOE reform in China only after this Decision was published in 1984.

${ }^{9}$ Article 15 of Chinese Constitution of 1982 declared that "the State practices planned economy on the basis of socialist public ownership." Such language was replaced by "the State practices socialist market economy" when the NPC amended the Constitution on March 29, 1993. See Zhonghua Renmin Gongheguo Xianfa Xiuzheng An (Amendments to the Constitution of People's Republic of China), passed by the NPC on March 29, 1993.

10 Prior to the Constitutional Amendments of 1993 referring to these entities as "State-owned enterprises," SOEs had been referred to as "State-managed enterprises" (Guoying Qiye). On March 29 of 1993, the Constitutional Amendments adopted the language of "State-owned enterprises" to replace the old term of "Statemanaged enterprises." LIU JUNHAI, GuFEN YOUXIAN GONGSI GIDONGQUA DE BAOHU (PROTECTION OF SHAREHOLDER'S RIGHTS) 336, PRESS OF LAW (Beijing, China, 1997).

${ }^{11}$ The Decision on SOEs Reform of 1999 declares that "official rankings should not be granted to enterprises and their leaders any more." This means that SOE executives are no longer treated as government officials.

${ }^{12}$ For instance, the typical traditional SOE offered housing benefits to their employees. American workers seldom enjoy such benefits.

${ }^{13}$ For instance, the State Council enacted several provisions on expanding the autonomous managerial powers enjoyed by SOEs in 1979, enacted Provisional regulations on SOEs in 1983, and enacted several provisions on deepening enterprise reforms and increasing enterprise vigor in 1986, etc.

${ }^{14}$ Zhonggong Zhongyang Guanyu Jingji Tizhi Gaige De Jueding (The Decision of the Central Committee of Chinese Communist Party on Several Issues Concerning the Reform of Economic System), RENMIN Chubanshe (PeOple's PRESS), 1984.

${ }^{15} I d$.

${ }^{16}$ This language was used only to qualify the language "dispose of," not "possess" and "use."

${ }^{17}$ SOEs Law $\$ 2$ (1988).

${ }^{18} \mathrm{Id}$. at $\$ 7$.

${ }^{19} I d$. at $\$ 45$.

${ }^{20}$ Id. at $\$ 47$.

${ }^{21} \mathrm{Id}$. at $\$ 8$.

${ }^{22} I d$. at $\$ 10$.

${ }^{23}$ Id. at $\$ 11$.

${ }^{24}$ Ding Genxi \& Zhang Jianping, Brave Exploration and Stablemarch: SOE Reform in Progress, ECONOMIC REFERENCE DAILY, Oct. 26, 1998, at 2. The State Council enacted the Provisional Regulations on Contracting Management System in SOEs on February 27, 1988. In 1994, the government required SOEs completing contracting terms to not renew contracts. Yang Peixin, Reexamination of Contracting System, ECONOMIC REFERENCE DAILY, Nov. 24, 1998, at 4.

${ }^{25}$ The Provisional Regulations on Contracting Management System in SOEs $§ 14$ (1988).

${ }^{26} I d$. at $\$ \$ 26-28(1988)$.

${ }^{27} I d$. at $\$ 30(1988)$.

${ }^{28} I d$. at $\$ 5$ (1988).

${ }^{29}$ Yang Peixin, Reexamination of Contracting System, ECONOMIC REFERENCE DAILY, Nov. 24, 1998, at 4.

${ }^{30}$ Ding Genxi \& Zhang Jianping, Brave Exploration and Stable March: SOE Reform in Progress, ECONOMIC REFERENCE DAILY, Oct. 26, 1998, at 2.

${ }^{31} I d$.

${ }^{32} I d$.

${ }^{33} I d$.

${ }^{34} I d$.

35 The wording "modern enterprises" triggered heated debates regarding its exact meaning in China. "Modern enterprises" could refer to various enterprises existing in [the] modern market economy, including modern partnerships, modern co-operatives, modern proprietorship, modern corporations and other derivative enterprise forms, such as the European Economic Interest Groups (EEIGs) in the European Union. However, the most 
suitable modern enterprises for SOE restructuring are modern corporations, especially publicly held corporations, including listed corporations.

${ }^{36}$ Decision on SOEs Reform, 15th CPC Central Committee (Sept. 22, 1999).

${ }^{37}$ Id. Some Western scholars are inclined to use the term "privatization of SOEs" to describe the process of SOE reform. In China the term "corporatization of SOE" is used instead of "privatization of SOEs" in the official documents. One of the reasons is that corporatization of SOEs is not a tool for encouraging privatization, but rather a tool for "magnifying the functions of State capital."

${ }^{38}$ Under Article 57 of the Constitution of People's Republic of China of 1982 (Constitution), the NPC is "the supreme state power organ." Pursuant to Article 62 (3) of the Constitution, the NPC has the power to enact and amend criminal law, civil law, state organ law, and other basic laws.

${ }^{39}$ Article 67 (2) of the Constitution gives the Standing Committee of the NPC the power to enact and amend laws other than those already enacted and amended by NPC itself.

40 The Corporate Law (Gongsi Fa) of 1993 (Corporate Law or Law) is the first comprehensive piece of legislation on business corporations since 1949 when the People's Republic of China was founded.

${ }^{41}$ Securities Law of 1998. In addition, other legal sources include administrative regulations promulgated by the central government, the State Council and its ministries. For example, in recent years, the State Council promulgated the following two acts: the Special Regulations for Overseas Listed and Traded Shares of Corporations Limited by Shares (July 4, 1994), and the Regulations for Domestically-Listed Shares Held Overseas of Corporations Limited by Shares (December 25, 1995). The State Committee of Economy and Trade and China Securities Regulatory Commission (CSRC) promulgated the Measures on Further Promoting Standardized Operations and Deepening the Reform in Overseas-Listed Corporations (Mar. 29, 1999).

Local legislatures also have power under the Constitution and the Legislation Law of 2000 to enact local regulations which do not conflict with national legislation.

${ }^{42}$ The Corporate Law requires that the memorandum of associations (Memorandum) be formulated when a company is incorporated, and provides that it shall be binding on the company, its shareholders, directors, supervisors and managers. See Corporate Law $\S 11,22,29$.

${ }^{43}$ The CSRC promulgated two administrative regulations to provide the guidelines for listed corporations in the formulation of their memorandum of associations. The first guideline is "the Indispensable Provisions of Memoranda of Associations in Overseas-Listed Corporations" of Sept. 29, 1994, and the second is "the Guidelines on Memorandums of Associations in Listed Corporations" of Dec. 16, 1997. The former deals with overseas-listed corporations, and the latter deals with generally listed corporations.

${ }^{44}$ For specific provisions regarding the general meeting of shareholders, see $\$ \$ 37-44,102-110$ Corporate Law (1993). For provisions concerning the board of directors, see $\S \S 45-49,51,68,112-18$ Corporate Law (1993). Provisions with respect to the board of supervisors can be found at $\$ \$ 2-54$ Corporate Law (1993).

${ }^{45}$ For the legal status of the chair, see Corporate Law $\S \S 45,113-14$ (1993). For the legal status of the CEO, see Corporate Law $\$ \$ 50,69,119$ (1993). However, because the Chair is a member of board of directors, and the $\mathrm{CEO}$ is an employee and agent of the corporation, they are generally treated within the framework of the three above-mentioned corporate bodies. Additionally, the Corporate Law provides that the vice-Chair of the board shall assist the Chair and shall, upon authorization by the Chair, perform the Chair's duties on behalf of the Chair in case the Chair is unable to perform his duty. See §114, Corporate Law (1993). In practice, the secretary of the board of directors of listed corporations is also an indispensable corporate position. However, the board secretary is not recognized by the Corporate Law or the Securities Law. Instead, this function is required only by administrative regulations.

${ }^{46}$ German Stock Corporation Act (Aktiengesetz) (1965); Fort \& Schipani, supra note 2, at 852; Bradley et al., supra note 2, at 52-53. See also, e.g., Thomas J. Andre, Jr., Some Reflections on German Corporate Governance: A Glimpse At German Supervisory Boards, 70 TUL. L. REV. 1819 (June 1996) (explores the composition of the supervisory boards of the largest German companies and attempts to document the frequency and extent of the supervisory board relationships among those companies); Susan-Jacqueline Butler, Models of Modern Corporations: A Comparative Analysis of German and U.S. Corporate Structures, 17 ARIZ. J. INT'L \& COMP. L. 555 (Fall 2000) (provides a detailed analysis of German and U.S. corporate law); David Charny, The German Corporate Governance System, 1998 CoLUM. Bus. L. REV. 145 (1998) (discussing the basic features of German corporate governance); Jeffrey N. Gordon, Pathways to Corporate Governance? Two Steps on the Road to Shareholder Capitalism in Germany, 5 COLUM. J. EUR. L. 219 (Spring 1999) (discusses the influence of cross-border stock mergers on the corporate governance landscape in the context of two recent transactions); Joaquin F. Matias, From Work-Units to Corporations: The Role of Chinese Corporate Governance in a Transitional Market Economy, 12 N.Y. INT'L L. REV. 1 (Winter 1999) (explores the tension between Chinese corporations and the government within the context of corporate governance); Oliver Seiler \& Bernd Singhof, Shareholder Participation in Corporate Decisionmaking Under German Law: A Comparative Analysis, 24 BROOK. J. INT'L L. 493 (1998) (discusses the structural rules that govern the decision-making power in German 
corporations).

47 Chinese Corporate Law, §§ 38(2),(3), 103(2),(3) (1993).

48 German Stock Corporation Act (Aktiengesetz), §111 (1965); Fort \& Schipani, supra note 2, at 852; Bradley et al., supra note 2, at 52-53. See also Andre, Jr., supra note 46; Butler, supra note 46; Charny, supra note 46; Gordon, supra note 46; Matias, supra note 46.

${ }^{49}$ Corporate Law $\$ 2$ (1993).

${ }^{50}$ The general meeting of shareholders, the board of directors, and the board of supervisors are mandatory for both types of corporations. In both types of corporations, the board of directors and the board of supervisors function on an equal level, and are independent from each other. In both types of corporations, the general meeting of shareholders, as the supreme authority of the corporation, has indisputable power to hold the two boards accountable. The wording used in the Corporate Law with respect to the duties of the general meeting of shareholders ( $\$ 38-103)$, the board of directors ( $\S 46-112)$, the CEO, ( $\S 50-119)$, and the board of supervisors $(\S \S 54-126)$, are substantially similar.

${ }^{51}$ Corporate Law §51, 52 (1993).

${ }^{52}$ Corporate Law $\$ 41$ (1993).

${ }^{53}$ Corporate Law $\$ 35$ (1993).

${ }^{54}$ Corporate Law $\$ 64$ (1993).

${ }^{55}$ Corporate Law $\$ 66$ (1993).

${ }^{56}$ Id.

${ }^{57}$ SOEs are governed by legislation predating enactment of the Corporate Law, the SOEs Law of 1988. For instance, under the SOEs Law of 1988, an SOE is defined as "a socialist commodity production and operation unit which, shall make its own managerial decisions, take full responsibility for its profits and losses and practice independent accounting in accordance with law.” See SOEs Law §2 (1988). Although Article 2 of this Law recognized that "SOEs shall obtain the status of legal person in accordance with law and bear civil liability," it did not recognize SOEs as business corporations in the sense of western company law, or even in the sense of the Corporate Law of 1993. Despite that both SOEs and wholly State-owned corporations are invested by the State or the government, SOEs under the regime of SOE Law of 1988 enjoy significantly fewer autonomous powers than wholly State-owned corporations under the Corporate Law of 1993. SOEs operating under the SOE Law of 1988 have neither a board of directors, nor a chair of the board. The only power center is the general manager or CEO. Under the Corporate Law, wholly State-owned corporations are required to establish a board of directors and a chair of the board in addition to a CEO. China is now determined to "introduce standardized corporate system reform into large and medium-sized SOEs." Decision of the Central Committee of the Chinese Communist Party on Major Issues Concerning the Reform and Development of SOEs, adopted at the 4th Session of the 15th CPC Central Committee on September 22, 1999 (Decision on SOEs Reform). For the English text of this decision, see <http://english.peopledaily.com.cn/199909/27/enc_19990927001005_TopNews.html> In other words, large and medium-sized SOEs will be encouraged to be transformed into either wholly State-owned corporations, closely held corporations or publicly held corporations.

${ }^{58}$ As the director of the State Council Office of Legislative Affairs, indicated "although the Corporate Law has clear provisions regarding the composition and function of the board of supervisors in closely held corporations and publicly held corporations, it is silent on the board of supervisors in wholly State-owned corporations. In reality, many financial and managerial problems exist in wholly State-owned corporations." See Cui Shixin, Yang Jingyu Explains the Corporate Law Amendments, PEOPLE'S DAILY, Dec. 18, 1999, at E.

${ }^{59}$ Quanguo Renmin Dabiao Dahui Changwu Weiyuanhui Guanyu Xiugai Gongsifa De Jueding (The Decision on Amending Corporate Law by the Standing Committee of the NPC) (1999). See PEOPLE'S DAILY, Dec. 18, 1999, at E.

${ }^{60} I d$.

${ }^{61} I d$. The State Council is considered the central government in China. It is the supreme executive branch and is responsible to the NPC.

62 This Law was enacted by the NPC on April 12,1986.

${ }^{63}$ This Law was enacted by the NPC on July 1,1979, and was amended by the NPC on April 4, 1990.

${ }^{64}$ This Law was enacted by the NPC on April 13,1988.

${ }^{65}$ Corporate Law $\$ 18$ (1993).

${ }^{66}$ Wholly Foreign-Invested Enterprise Law of 1986.

${ }^{67}$ Chinese-Foreign Equity Joint Ventures Law \$4 (1979).

${ }^{68}$ Chinese-Foreign Equity Joint Ventures Law §6 (1979).

${ }^{69}$ Id. at \$4(1) (1979).

${ }^{70}$ Chinese-Foreign Contractual Joint Ventures Law §2(1) (1988).

${ }^{71}$ Chinese-Foreign Equity Joint Ventures Law §4(3) (1979). 
${ }^{72}$ Chinese-Foreign Contractual Joint Ventures Law §22(1) (1988).

${ }^{73}$ Chinese-Foreign Equity Joint Ventures Law §4(3) (1979).

${ }^{74}$ Chinese-Foreign Contractual Joint Ventures Law §22(2) (1988).

${ }^{75}$ Chinese-Foreign Equity Joint Ventures Law §6(1979); Chinese-Foreign Contractual Joint Ventures Law $§ 12$ (1988).

${ }^{76}$ Corporate Law $\$ 2$ (1993).

${ }^{77}$ Corporate Law $\$ 151$ (1993).

78 See, e.g., Chapters 3, 4 and 5 of the Corporate Law of 1993.

79 See, e.g., Chapters 2, 3 and 4 of the Securities Law of 1998.

${ }^{80} \mathrm{Id}$.

${ }^{81}$ Each shareholder shall pay the capital contribution subscribed for under the articles of association of the company in full. If a shareholder makes its capital contribution in currency, it shall deposit the full amount of such capital contribution in currency in the interim bank account opened by the limited liability company to be established. If a shareholder makes its capital contribution in the form of material objects, industrial property rights, non-patented technology or land-use rights, the transfer procedures for the particular property rights shall be handled in accordance with the law. See Corporate Law §25 (1993).

${ }^{82}$ Id.

${ }^{83}$ Corporate Law $\$ 75$ (1993).

${ }^{84}$ Corporate Law $\$ 159$ (1993).

${ }^{85}$ Survey Team of Reform in 100 Pilot SOEs \& Cheng Yuan, Enterprises Demand Supportive Reforms, JINGJI RIBAO (ECONOMIC DAILY), Jan. 10, 2000, at 5.

${ }^{86} \mathrm{Id}$.

${ }^{87} \mathrm{Id}$.

${ }^{88} \mathrm{Id}$.

${ }^{89} \mathrm{Id}$.

${ }^{90} I d$. Many SOEs at the local levels have also been corporatized. For example, approximately $40 \%$ of the large and medium-sized SOEs in the Liaoning Province have been transformed into corporations, twenty-six listed corporations have raised RMB 13.8 billion Yuan (US\$ 1.66 billion) of capital by issuing stocks, and one-third of these enterprises were out of difficulty by September of 1999. See China Daily Briefs, State Firms Start to Make Profits, CHINA DAILY, Sept. 21,1999.

${ }^{91}$ China Confederation of Enterprises, The Comments and Proposals from SOE Managers. ZHONGGUO JINGJI Shibao (China ECONOMIC Times), Sept. 2, 1999, at 5.

${ }^{92} I d$.

${ }^{93} \mathrm{Id}$.

${ }^{94}$ Zhao Huanxin, State Assets Need to be Restructured, CHINA DAILY, Sept. 22, 1999. Among over 238,000 non-commercial SOEs, only 170 SOEs are under the direct supervision of the central government. See Che Haigang \& Bo Jingwei, Corporate Governance in SOEs Should not be too Exceptional, ZHONGGUO JINGJI SHIBAO (CHINA ECONOMIC TIMES), Jan. 21, 2000, at 2.

${ }^{95}$ Zhao Huanxin, Training to Improve Management of SOEs, CHINA DAILY, Jan. 30, 1999.

${ }^{96}$ Survey Team of Reform in 100 Pilot SOEs \& Cheng Yuan, Enterprises Demand Supportive Reforms, JINGJI RIBAO (ECONOMIC DAILY), Jan. 10, 2000, at 5.

${ }^{97}$ Id.

${ }^{98} I d$.

${ }^{99} \mathrm{Id}$.

${ }^{100} \mathrm{Id}$.

${ }^{101}$ Wang Yanchun, Che Haigang \& Zhao Ming, Listed Corporations Walking on the Old Way in New Shoes, ZhongGuo Jingui SHIBAO (CHINA ECONOMIC TIMES), Jan. 20, 2000, at 1.

102 See Chen Qingtai, The Chair is Not the Number One Leader in the Corporation, RENMIN RIBAO (PEOPLE'S DAILY), Jan.10, 2000, at 12.

${ }^{103}$ Wang Yanchun, Che Haigang \& Zhao Ming, Listed Corporations are Walking on the Old Way in New Shoes, ZhongGuo Jingu SHIBAO (CHINA ECONOMIC TIMES), Jan. 20, 2000, at 1.

${ }^{104}$ Chen Qingtai, Dongshizhang Bushi Yibashou (The Chair is not the Number One Leader in the Corporation), RENMIN RIBAO (PEOPLE'S DAILY), Jan. 10, 2000, at 12.

${ }^{105}$ Wang Yanchun, Che Haigang \& Zhao Ming, Listed Corporations are Walking on the Old Way in New Shoes, ZhongGuo Jingu SHIBAo (CHINA ECONOMIC TIMES), Jan. 20, 2000, at 1.

${ }^{106} I d$.

107 The subsidiary administrative regulation is called the Regulations on Transformation of Management Mechanism in SOEs of 1992.

108 Liu Junhai, Gufen Youxian Gongsi Gundongquan De BaOHu (Protection of ShareholdeR's 
RIGHTS), PRESS OF LAW 336 (Beijing, China, 1997).

${ }^{109}$ Enterprise Needs Management Freedom, CHINA DAILY, Jan. 16, 1999, at 4.

${ }^{110}$ China Confederation of Enterprises, The Comments and Proposals From SOE Managers. ZHONGGUO JINGJI Shibao (China ECONOMIC TIMES), Sept. 2, 1999, at 5.

${ }^{111} I d$.

${ }^{112} \mathrm{Id}$.

${ }^{113} I d$.

${ }^{114} I d$.

${ }^{115} I d$.

${ }^{116} \mathrm{Id}$.

${ }^{117} \mathrm{Id}$.

118 The most comprehensive official interpretation on the separation between corporation and government (Zhengqi Fenkai) reads as follows: "The government performs the functions of shareholders in the SOEs or state share-holding corporations via its designated representatives, enjoys the rights to share profits from assets, make major decisions and select managers in accordance with the scale of investment, bears limited responsibilities for enterprises' debts, and will not interfere in the daily operations of enterprises. Enterprises will operate business independently according to law, pay taxes in accordance with relevant regulations, be responsible for preserving and increasing the value of the net assets of the owners, and not be allowed to tamper with the legitimate rights of the owners. In terms of personnel and financial management, Party and government agencies at different levels should fully separate themselves from the economic entities they run or enterprises they directly administer." Decision on SOEs.

119 Measures on Further Promoting Standardized Operations and Deepening the Reform in Overseas-Listed Corporations (1999). "[T]he administrative subordinate relations between the corporations and government agencies should be renounced and their relations in assets, finance, personnel management and other aspects must be thoroughly separated. Government agencies are not allowed to interfere in the production and operational management of the Corporations, and must not collect from the Corporations management fees or supervisory fees in whatever forms."

${ }^{120}$ Professor Asbjorn Eide at Norwegian Institute of Human Rights described the responsibilities of the political states in promoting the human rights as the obligation to respect, the obligation to protect, the obligation to facilitate and the obligation to fulfill. See A. Asbjorn Eide, The Human Rights Requirements to the Social and Economic Development, Food PoliCy, Mar. 1996, London. See also see Liu Junhai, Legal Strategies for Preventing Financial Crisis, 1 ACADEMIC Journal OF CHINA LAW SOCIETY (Beijing, 1999).

${ }^{121}$ Decision on SOEs Reform.

${ }^{122} \mathrm{Id}$.

${ }^{123} I d$.

${ }^{124}$ Decision on SOEs Reform.

${ }^{125}$ Corporate Law $\$ 37,102$ (1993).

126 Corporate Law $\$ \S 38,103$ (1993). In addition to the above-mentioned powers enjoyed by the general meetings of shareholders in both closely and publicly held corporations, the meeting of shareholders in closely held corporations enjoy two extra powers, including the power "to adopt resolutions on the assignment of capital contribution by a shareholder to a person other than the shareholders," and to "to adopt resolutions on the change of corporate forms." Corporate Law $\$ 38$ (1993). These two powers are not available to the shareholders in publicly held corporations. Shareholders in publicly held corporations enjoy more freedom in transferring their shares to third parties. Privately held corporations may be transformed into publicly held corporations, while publicly held corporations may not be transformed into privately held corporations.

${ }^{127}$ ZHONGHUO RENMIN GONGHEGUO XIANFA (CONSTITUTION OF THE PEOPLE'S REPUBLIC OF CHINA) §57 (1982).

${ }^{128} I d$. at $\$ 3$ (1982).

${ }^{129}$ Chen Hongyu, Boring General Meetings of Shareholders, CHINA SECURITIES DAILY, May 11, 2000.

${ }^{130} \mathrm{Id}$.

${ }^{131} \mathrm{Id}$.

${ }^{132} \mathrm{Id}$.

${ }^{133} I d$.

${ }^{134}$ Id.

${ }^{135}$ Chen Xue, Meetings of Shareholders are Not Silent, ZHONGGUO ZHENGQUAN BAO (CHINA SECURITIES DAILY), June 1, 2000, at 1.

${ }^{136} \mathrm{Id}$.

${ }^{137} \mathrm{Id}$.

${ }^{138} \mathrm{http}: / / \mathrm{www} . p e o p l e d a i l y . c o m . c n / z c x x / 2000 / 05 / 052611 . \mathrm{html}$ [Visited on 9-16-01]

139 The Standard Opinions on Meeting of Shareholders in Listed Corporations $§ 19$ (2000). 
${ }^{140}$ The CSRC Notice on issuing the Standard Opinions on Meeting of Shareholders in Listed Corporations. See http://www.peopledaily.com.cn/zcxx/2000/05/052611.html. [Visited on 9-16-01]

${ }_{141}$ Zhou Dao, Shareholders May also Convene Meeting of Shareholders, ZHONGGuO ZHENGQUANBAO (CHINA SECURITIES DAILY), Sept. 28, 2000, at 7.

${ }^{142}$ Id.

${ }^{143} \mathrm{Id}$.

144 The Standard Opinions on Meeting of Shareholders in Listed Corporations $\$ 34$ (2000).

${ }^{145}$ Corporate Law $\$ 110$ (1993).

146 MELVIN ARON EISENBERG, CORPORATIONS AND OTHER BuSINESS ORGANIZATIONS 157-62 (8TH ED. 2000).

${ }^{147}$ Corporate Law $\$ 114$ (1993).

${ }^{148} \mathrm{Id}$.

${ }^{149} \mathrm{Id}$.

${ }^{150}$ Corporate Law $\$ 113(1993)$.

${ }^{151}$ Corporate Law $\$ 120$ (1993). However, the Chair may not exercise these powers unless he or she has valid authorization from the board of directors.

${ }^{152}$ Corporate Law $\$ 117$ (1993).

${ }^{153} I d$.

${ }^{154}$ The CEO enjoys great statutory managerial powers, including but not confined to, the responsibility to direct corporate production, operation and management, to organize the implementation of resolutions of the board of directors, and to organize the implementation of annual corporate business plans and investment plans, etc. The CEO is also entitled to observe the meetings of the Board of directors. See Corporate Law $\$ 119$ (1993).

${ }^{155}$ Corporate Law $\$ 119$ (1993).

${ }^{156} I d$. at $\$ \$ 50,119(1993)$.

${ }^{157}$ Corporate Law $\$ 119$ (1993).

${ }^{158}$ This problem has been identified by other authors. See, e.g., Chen Qingtai, The Chair is Not the Number One leader in the Corporation, RENMIN RIBAO (PEOPLE'S DAILY), Jan. 10, 2000, at 12.

${ }^{159}$ MODEL BUSINESS CORPORATION ACT $\$ 8.01$ (b) (1999).

160 AmERicAN LAW Institute, Principles of CORPORATE GOVERnANCE, ANALYSis AND RECOMMENDATIONS $\$ 3.02(1994)$.

${ }^{161}$ MOdel Business CORPORATION ACT, Official Comment to $\$ 8.25$ (1999).

162 China Securities Regulatory Commission, Measures on Further Promoting Standardized Operations and deepening the Reform in Overseas-Listed Corporations, §5 (1999).

${ }^{163}$ Model Business Corporation Act $\$ 8.25$ (f) (1999).

164 See Zhang Yiyong, Independent Directors should not Become the "Deaf Ears," JINGJI RIBAO (ECONOMIC DAILY), July 10, 2000, at 2.

${ }^{165}$ Measures on Further Promoting Standardized Operations and Deepening the Reform in Overseas-Listed Corporations $§ 6$ (1999). This document defines "outside directors" as "directors who do not hold posts within the corporations;" and defines "independent directors" as "directors independent of the shareholders of the corporations and holding no positions in the corporations." Thus, it seems that this document subclassifies outside directors into the categories of independent directors and non-independent directors.

${ }^{166} I d$.

167 Id.

${ }^{168}$ Guidelines on Memorandum of Associations in Listed Corporations §112 (1997).

169 The Basic Regulations for Large and Medium-Sized SOEs to Build up Modern Enterprise System and Strengthen Governance $\$ 7$ (2000).

170 Zhang Wei, Lanzhou-Based Huanghe Corporation: A Big Mess, ZHONGGUO JINGJI SHIBAO (CHINA ECONOMICS TIMES), Jan. 11, 2001 at 2.

${ }^{171}$ Zhang Yiyong, Independent Directors Should not Become the "Deaf Ears," JINGJI RIBAO (ECONOMIC DAILY), July 10, 2000, at 2.

${ }^{172}$ Luo Xinyu, Embarrassed Independent Directors, ChINA YouTH DAILY, Jan. 13, 2000.

${ }^{173} I d$.

${ }^{174} I d$.

${ }^{175} \mathrm{Id}$.

${ }^{176}$ Ding Pinyu, How to Make Supervision Effective in SOEs, RENMIN RIBAO (PEOPLE'S DAILY), June 9, 1998, at 11 .

${ }^{177} I d$.

${ }^{178}$ Cui Shixin, Do not Put the Fate of an Enterprise into One Person's Hand, RENMIN RIBAO (PEOPLE'S DAILY), Apr. 21,1998, at 11 .

${ }^{179}$ Ding Pinyu, How to Make Supervision Effective in SOEs, RENMIN RIBAO (PEOPLE'S DAILY), June 9, 1998, at 
11.

${ }^{180}$ Cui Shixin, Do Not Put the Fate of an Enterprise into One Person's Hand, RENMIN RIBAO (PEOPLE'S DAILY), Apr. 21,1998, at 11 .

${ }^{181} I d$.

${ }^{182} \mathrm{Id}$.

${ }^{183}$ Zhang Zhuoyuan, Which Sort of Corporate Governance Structure will China Need? CHINA ECONOMIC DAILY, Apr. 19, 2000, at 5.

${ }^{184} I d$.

${ }^{185}$ Ding Pinyu, How to Make Supervision Effective in SOEs, RENMIN RIBAO (PEOPLE'S DAILY), June 9, 1998, at 11.

${ }^{186} \mathrm{Id}$.

${ }^{187}$ Cui Shixin, Do Not Put the Fate of an Enterprise into One Person's Hand, RENMIN RIBAO (PEOPLE'S DAILY), Apr. 21,1998, at 11.

${ }^{188}$ China Confederation of Enterprises, The Comments and Proposals from SOE Managers, ZHONGGUO JINGJI SHIBAo (CHINA ECONOMIC TIMES), Sept. 2, 1999, at 5.

${ }^{189}$ Michael Bradley \& Cindy A. Schipani, The Relevance of the Duty of Care in Corporate Governance, 75 IOwA L. REV. 1, 16-28 (1989); Cindy A. Schipani, Integrating Corporate Law Principles with CERCLA Liability for Environmental Hazards, 18 DEL. J. CORP. L. 1, 11-22 (1993). See also, e.g., Robert Cooter \& Bradley J. Freedman, The Fiduciary Relationship: Its Economic Character and Legal Consequences, 66 N.Y.U. L. REV. 1045 (October 1991) (describes different economic risks and how the duty of loyalty and duty of care affects these risks); Harry G. Hutchison, Presumptive Business Judgement, Substantive Good Faith, Litigation Control: Vindicating the Socioeconomic Meaning of Harlan v. Brown, 26 IOWA J. CORP. L. 285 (Winter 2001) (looks at a recent Massachusetts Appeals Court case that amplifies a debate as to whether courts should engage in a procedural or a substantive review of the board's attempt to control litigation).

${ }^{190}$ Cui Shixin, Do not Put the Fate of an Enterprise into One Person's Hand, RENMIN RIBAO (PEOPLE'S DAILY), Apr. 21,1998, at 11.

${ }^{191}$ Corporate Law $\$ \$ 59,60,61,62,63$ (1993).

${ }^{192}$ Corporate Law $\$ \$ 214,215$ (1993).

193 AMERICAN LAW InSTITUTE, PRINCIPLES OF CORPORATE GOVERNANCE §4.01(a) (1994).

194 EISENBERG, supra note 146 at 651-66; Harvey Gelb, Corporate Governance Guidelines-A Delaware Response, 1 WYO. L. REV. 523 (2001) (examines governance guidelines involving board independence and director liability for breaches of fiduciary duty); William S. Laufer, Corporate Liability, Risk Shifting, and the Paradox of Compliance, 52 VAND. L. REV. 1343 (October 1999) (discusses the evolution of corporate criminal law in the United States, the evolution away from entity liability, and the emergence of the good citizen corporation movement); Kenji Utsumi, The Business Judgment Rule and Shareholder Derivative Suits in Japan: A Comparison with Those in the United States, 14 N.Y. INT'L L. REV. 129 (Winter 2001) (discusses the legal practice of and issues in shareholder derivative suits in both the United States and Japan).

195 Japanese Commercial Code $§ \S 267,268 \mathrm{a}, 268 \mathrm{~b}$, and 268c (1950).

${ }^{196}$ Zhou Hanmin, Consciousness is not the Most Reliable Stuff: Perspective on the Values of the SOE managers, 1 WINDOW OF SOUTH WIND 6 (Guangzhou, China, 1999).

${ }^{197} I d$.

${ }^{198} I d$.

${ }^{199}$ Liu Jie, SOEs Offered Stock Options, CHINA DAILY, Jan. 25, 2000.

${ }^{200} I d$.

${ }^{201} I d$.

202 Id.

${ }^{203} I d$.

${ }^{204} I d$.

${ }^{205}$ Jing Xian, Officials Awarded Shares, CHINA DAILY, Jan. 21, 1999.

${ }^{206}$ Corporate Law $\$ 54,126$ (1993).

${ }^{207} \mathrm{Id}$. at $\$ \$ 52,124$ (1993).

${ }^{208} I d$.

${ }^{209}$ Survey Team of Reform in 100 Pilot SOEs \& Cheng Yuan, Enterprises Demand Supportive Reforms, JINGJI RIBAO (ECONOMIC DAILY), Jan. 10, 2000, at 5.

${ }^{210} I d$.

${ }^{211}$ Corporatization Should not Become A Camouflage, JingJI RIB AO (ECONOMIC DAILY), Nov. 2, 2000 , at 6.

${ }^{212}$ Xinhua, Premier Highlights Role of New System: Inspectors to Assist Reform, CHINA DAILY, May 11, 1998.

${ }^{213} I d$.

${ }^{214} I d$. 
215 As of June, 2000, there were 999 A or B Share listed companies, with a total market capitalization of 4069 billion Chinese Yuan (about 500 billion USD), negotiable market capitalization of 1322.909 billion Chinese Yuan (about 160 billion USD), stock turnover of 608.455 billion Chinese Yuan (about 72 billion USD). There are about 51.3034 million securities investors as a whole. See http://www.csrc.gov.cn/CSRCsite/eng/tongjiku/199908/ehtml/y2000/07/a200007.html [Visited on 9-16-01]

${ }^{216}$ See The Initial Public Offering of Petro China: A Report by the AFL-CIO's Office of Investment, at < http://www.petrochinawatch.com/ipo/>. [visited on 9-16-01]

${ }^{217}$ China Confederation of Enterprises, The Comments and Proposals from SOE Managers, ZHONGGUO JINGJI Shibao (China Economic Times), Sept. 2, 1999, at 5.

${ }^{218}$ Corporate Law $\$ 4$ (1993).

${ }^{219}$ Corporate Law $\$ 4$ (1993).

${ }^{220}$ Corporate Law $\$ 5$ (1993).

${ }^{221}$ In the end, the legislative language should be further refined when the Corporate Law of 1993 is amended. For instance, a more suitable term such as "corporate property ownership" should replace "corporate property rights." Similarly, the phrase "the ownership of State-owned assets in a corporation shall vest in the State" should be deleted, in order to permit the existence of sound corporate property ownership.

${ }^{222}$ Decision on SOEs Reform.

${ }^{223}$ China Confederation of Enterprises, The Comments and Proposals from SOE Managers, ZHONGGUO JINGJI SHIBAo (CHINA ECONOMIC TIMES), Sept. 2, 1999 at 5.

${ }^{224} I d$.

${ }^{225}$ Decision on SOEs Reform.

${ }^{226}$ Chen Qingtai, The Chair is Not the Number One Leader in the Corporation, RENMIN RIBAO (PEOPLE'S DAILY), Jan. 10, 2000, at 12.

${ }^{227}$ Corporate Law $\$ 64$ (1993).

${ }^{228}$ Further interpretation of the phrase "special products" is expected. The Decision on SOEs Reform declared that "industries and sectors that need to be controlled by the State economy include: industries that are related to State security; industries that are naturally monopolized; industries that supply major products and services for the public; and pillar industries and backbone enterprises in high and new technology sectors. In other industries and fields, the entire quality of the State economy could be improved through regrouping the assets and readjusting the structure to centralize their capacity and strengthen the key SOEs." However, it does not provide an exact definition for the term "special products." Rather, it lists the industries in need of control by the State. The exact meaning of "special products" should be interpreted as flexible as possible so as to accommodate industry changes.

${ }^{229}$ Under current practice, there are annual ceiling requirements regarding the number of newly-listed corporations. In this way, not all the corporations satisfying the statutory listing requirements are permitted to be listed on the securities exchanges.

${ }^{230}$ Guanyu Dui Ni Faxing Shangshi Qiye Gaizhi Qingkuang Jinxing Diaocha De Tongzhi (The Notice on Survey of Restructured Enterprises Proposed to be Listed) of 1998; Guanyu Shangshi Gongsi Peigu Gongzuo Youguan Wenti De Tongzhi (The Revised Notice on Distribution of New Shares in Listed Corporations) of 1999.

${ }^{231}$ Wen Che, Prevent the Insider Trading by Multiple Means, ZHONGGUO ZHENGQUANBAO (CHINA SECURITIES DAILY), Apr. 19, 2000, at 7.

${ }^{232} I d$.

${ }^{233} I d$.

${ }^{234} I d$.

${ }^{235} \mathrm{Id}$.

${ }^{236}$ Wen Che, Prevent the Insider Trading by Multiple Means, ZHOngGuo ZHENGQuANBAo (CHINA SECURITIES DAILY), Apr. 19, 2000, at 7.

${ }^{237} \mathrm{Li}$ Yinghong, Hard Porridge: The Obstacles Against the "Three-Separations" and Relevant Proposals on Venture Shares, at

< http://business.sohu.com/20000906/file/203,000,100124.html $>$. [Visited on 9-16-01]

238 Id.

${ }^{239} \mathrm{Id}$.

${ }^{240}$ Wen Che, Prevent the Insider Trading by Multiple Means, ZHONGGUO ZHENGQUANBAO (CHINA SECURITIES DAILY), Apr. 19, 2000, at 7.

${ }^{241}$ The issue of piercing the corporate veil is raised at different levels in China. Since Shenzhen is a Special Economic Zone in China, and its local congress enjoys certain legislative powers, some representatives at Shenzhen People's Congress proposed in early 2000 that this local congress should authorize the Court to apply the doctrine of piercing corporate veil on pilot basis. See Wang Li, Guanyu Jianyi You Renda Shouquan 
ShifaYuan Shixing Faren Zige Fouren Zhidu De Yijian (Proposal on Authorizing the Courts by the Shengzhen Congress to Apply the Doctrine of Piercing Corporate Veil on Pilot Basis), at <http://rdcwh.sz.gov.cn/RDconference/dhwj/gg06171.htm>. For a discussion of veil piercing theory in the United States, see Stephen M. Bainbridge, Abolishing Veil Piercing, 26 J. CoRP. L. 479 (Spring 2001) (discussing the history of limited liability and the veil piercing doctrine); John H. Matheson \& Raymond B. Eby, The Doctrine of Piercing the Veil in an Era of Multiple Limited Liability Entities: An Opportunity to Codify the Test for Waiving Owners' Limited-Liability Protection, 75 WASH. L. REV. 147 (Jan. 2000) (describing the history of veil piercing analysis and a proposal for an improved approach); Douglas C. Michael, To Know a Veil, 26 J. CORP. L. 41 (Fall 2000) (discussing the history and origins of veil piercing analysis as well as modern analysis); Dana M. Muir \& Cindy A. Schipani, The Intersection of State Corporation Law and Employee Compensation Programs: Is it Curtains for Veil Piercing?, 1996 ILL. L. ReV. 1059 (1996); Robert B. Thompson, Piercing the Corporate Veil: An Empirical Study, 76 CORNELl L. REV. 1036 (July 1991) (empirical study evaluating piercing the veil cases).

${ }^{242}$ A shares and B shares are divided based on citizenship differences of the investors. Therefore, a listed corporation could issue both A shares and B shares. A Shares are domestically-invested shares issued domestically by Chinese corporations. B Shares are foreign-invested shares issued domestically by Chinese corporations. B Shares are also known as Renminbi Special Shares. B Shares are issued in the form of registered shares and carry a face value denominated in Renminbi. B Shares are subscribed and traded in foreign currencies, listed and traded in securities exchanges inside China. According to scholars "although owners of the A and B shares share equal rights in the same corporations, they react to different underlying forces." Hung-Gay Fung, Wai Lee, \& Wai Kin Leung, Segmentation of the A- and B-Share Chinese Equity Markets, 22 THE JOURNAL OF FINANCIAL RESEARCH (Summer 2000). This research argues that "the segmentation of the A and B markets in China seems to provide profitable opportunities to U.S. companies that have access to both markets as the Chinese government deregulates the financial markets." Id.

${ }^{243}$ Theoretically speaking, most legal person shares belong to the State.

${ }^{244} \mathrm{H}$ shares are foreign-invested shares issued by Chinese domestic corporations, but listed at the exchanges in Hong Kong. For similar reasons, the foreign-invested shares issued by Chinese domestic corporations, but listed at the New York Stock Exchanges are called N shares.

${ }^{245}$ Yin Guohong, Stock Market Structure in 2000 Needs More Changes, ZhongGuO JingJi SHIBAO (CHINA ECONOMIC TIMES), Jan. 3, 2000, at 3.

${ }^{246}$ See http://www.CSRC.gov.cn/CSRCsite/eng/esmintr.htm [Visited on 9-16-01]

${ }^{247} \mathrm{Id}$.

${ }^{248}$ SOE Law $\$ 1$ (1988).

${ }^{249}$ The Regulations Concerning Transformation of Management Mechanism in SOEs, §1 (1992).

${ }^{250}$ Zhu Qiwen, Catch up by Raising Efficiency, CHINA DAILY, Jan. 17, 2000.

${ }^{251} I d$.

${ }^{252} I d$.

${ }^{253} I d$.

${ }^{254}$ Zhu Rongji, Government Working Report, submitted to the third session of the National People's Congress on March 5, 2000. See http://www.peopledaily.com.cn/zgrdxw/lianghui/news/0317/031701.html.

${ }^{255}$ See Decision of the Central Committee of the Chinese Communist Party on Major Issues Concerning the Reform and Development of SOEs, adopted at the 4th Session of the 15th CPC Central Committee on Sept. 22, 1999. 


\section{DAVIDSON INSTITUTE WORKING PAPER SERIES - Most Recent Papers}

The entire Working Paper Series may be downloaded free of charge at: www.wdi.bus.umich.edu

CURRENT AS OF 11/29/01

\begin{tabular}{|c|c|c|}
\hline Publication & Authors & Date \\
\hline No. 407: Corporate Governance in China: Then and Now & Cindy Schipani and Liu Junhai & Nov. 2001 \\
\hline No. 406: Entrepreneurship and Post-Socialist Growth & $\begin{array}{l}\text { Daniel Berkowitz and David N. } \\
\text { DeJong }\end{array}$ & Oct. 2001 \\
\hline No. 405: Policy Reform and Growth in Post-Soviet Russia & $\begin{array}{l}\text { Daniel Berkowitz and David N. } \\
\text { DeJong }\end{array}$ & Oct. 2001 \\
\hline $\begin{array}{l}\text { No. 404: Social Policies and Structures: Institutional Frictions and Traps } \\
\text { in the Czech Republic after } 1989\end{array}$ & Jiř́i Večerník & Nov. 2001 \\
\hline $\begin{array}{l}\text { No. 403: Investment, Efficiency, and Credit Rationing: Evidence from } \\
\text { Hungarian Panel Data }\end{array}$ & Mathilde Maurel & Nov. 2001 \\
\hline $\begin{array}{l}\text { No. 402: Subduing High Inflation in Romania. How to Better Monetary } \\
\text { and Exchange Rate Mechanisms? }\end{array}$ & $\begin{array}{l}\text { Daniel Daianu and Radu } \\
\text { Vranceanu }\end{array}$ & Aug. 2001 \\
\hline $\begin{array}{l}\text { No. 401: The Gender Wage Gap in Bulgaria: A Semiparametric } \\
\text { Estimation of Discrimination }\end{array}$ & Dean Jolliffe & July 2001 \\
\hline $\begin{array}{l}\text { No. 400: Do External Auditors Perform a Corporate Governance Role in } \\
\text { Emerging Markets? Evidence from East Asia }\end{array}$ & Joseph P. H. Fan and T.J. Wong & Oct. 2001 \\
\hline $\begin{array}{l}\text { No. 399: Financial Conditions and Investment during the Transition: } \\
\text { Evidence from Czech Firms }\end{array}$ & Lubomír Lízal and Jan Svejnar & Oct. 2001 \\
\hline $\begin{array}{l}\text { No. 398: Accessible Pareto-Improvements: Using Market Information to } \\
\text { Reform Inefficiencies }\end{array}$ & Michael Mandler & May 2001 \\
\hline No. 397: The Making of an Integrated National Grain Market in China & jiao Zhou & Oct. 2001 \\
\hline No. 396: Corruption and Resource Allocation: Evidence from China & Wei Li & June 2001 \\
\hline $\begin{array}{l}\text { No. 395: Government Shareholding and the Value of China's Modern } \\
\text { Firms }\end{array}$ & Lihui Tian & Apr. 2001 \\
\hline No. 394: Labor Hoarding in Russia: Where Does it Come from? & $\begin{array}{l}\text { Rouslan Koumakhov and Boris } \\
\text { Najman }\end{array}$ & June 2000 \\
\hline $\begin{array}{l}\text { No. 393: Ownership Structure, Corporate Governance, And Firm Value: } \\
\text { Evidence from the East Asian Financial Crisis }\end{array}$ & Michael Lemmon and Karl Lins & Apr. 2001 \\
\hline No. 392: Marshall and Labour Demand in Russia: Going Back to Basics & $\begin{array}{l}\text { Jozef Konings and Hartmut } \\
\text { Lehmann }\end{array}$ & Aug. 2001 \\
\hline No. 391: Economic Transition and Elections in Poland & $\begin{array}{l}\text { John E. Jackson, Jacek Klich, and } \\
\text { Krystyna Poznańska }\end{array}$ & June 2001 \\
\hline $\begin{array}{l}\text { No. 390: Effects of Bank Insolvency and Strategic Uncertainty on } \\
\text { Corporate Restructuring in Transition Economies }\end{array}$ & Christa Hainz & Aug. 2001 \\
\hline No. 389: Mark-Up Pricing In Bulgarian Manufacturing & $\begin{array}{l}\text { Rumen Dobrinsky, Boyko } \\
\text { Nikolov, and Nikolay Markov }\end{array}$ & June 2001 \\
\hline $\begin{array}{l}\text { No. 388: Globalization and Firms' Financing Choices: } \\
\text { Evidence from Emerging Economies }\end{array}$ & $\begin{array}{l}\text { Sergio Schmukler and Esteban } \\
\text { Vesperoni }\end{array}$ & May 2001 \\
\hline $\begin{array}{l}\text { No. 387: The Distributional Impacts of Indonesia's Financial Crisis on } \\
\text { Household Welfare: A "Rapid Response" Methodology }\end{array}$ & $\begin{array}{l}\text { Jed Friedman and James } \\
\text { Levinsohn }\end{array}$ & Sept. 2001 \\
\hline $\begin{array}{l}\text { No. 386a: Corporate Financial Policies and Performance Around } \\
\text { Currency Crises }\end{array}$ & $\begin{array}{l}\text { Arturo Bris, Yrjö Koskinen, and } \\
\text { Vicente Pons }\end{array}$ & Oct. 2001 \\
\hline No. 385: Ownership and Productive Efficiency: Evidence from Estonia & Derek C. Jones and Niels Mygind & Aug. 2001 \\
\hline $\begin{array}{l}\text { No. 384: Forthcoming in: Journal of Economic Perspectives, } \\
\text { "Institutional Determinants of Labor Reallocation in Transition" Vol. } \\
\text { 16, No. 2, Feb. } 2002 \text {. }\end{array}$ & Tito Boeri and Katherine Terrell & June 2001 \\
\hline $\begin{array}{l}\text { No. 383: Deindustrialisation and Structural Change During the Post- } \\
\text { Communist Transition }\end{array}$ & $\begin{array}{l}\text { Tomasz Mickiewicz and Anna } \\
\text { Zalewska }\end{array}$ & June 2001 \\
\hline No. 382: Markets and Growth & Štěpán Jurajda and Janet Mitchell & July 2001 \\
\hline
\end{tabular}

